\title{
Molecular systematics of New Zealand Cyanoramphus parakeets: conservation of Orange-fronted and Forbes' Parakeets
}

\author{
W. M. BOON, J. C. KEARVELL, C. H. DAUGHERTY and G. K. CHAMBERS
}

\begin{abstract}
Summary
The controversy that presently surrounds the taxonomy of the Orange-fronted Cyanoramphus malherbi and Forbes' C. forbesi Parakeets has important implications for the conservation of both birds. Both taxa are critically endangered, but consensus regarding their specific status has not yet been achieved. We present mitochondrial DNA sequences for the cytochrome $b$ gene and the control region from 17 Cyanoramphus parakeets representing nine populations and six taxa together with field observations of courtship and breeding behaviour in a sympatric population of Orange-fronted and Yellow-crowned Parakeets C. auriceps. Field data support species status of the Orange-fronted Parakeet under the Biological Species Concept. Phylogenetic analyses of our DNA sequence data support earlier hypotheses based on allozyme data that both Orange-fronted and Forbes' Parakeets represent distinct species under four species concepts and indicate that high conservation priority is warranted for both taxa.
\end{abstract}

\section{Introduction}

Parakeets of the genus Cyanoramphus (Psittacidae: Psittacinae) occur in the South Pacific from the tropics to the subantarctic (Taylor 1985) with their distribution centred in New Zealand (Figure 1, Table 1). Most taxa have limited ranges and are thus vulnerable to extinction (Taylor 1985). Most previous taxonomies have recognized three extant species and six subspecies of New Zealand Cyanoramphus parakeets (Turbott 1990), but a recent genetic study by Triggs and Daugherty (1996) claimed that five extant species should be recognized, elevating two of the rarest and most endangered forms, Forbes' Parakeet and Orange-fronted Parakeet to full species status: $C$. forbesi and C. malherbi respectively. However, this view has subsequently been challenged by Taylor (1998). In this study, we follow the Cyanoramphus parakeet nomenclature as recommended by Triggs and Daugherty (1996).

\section{Conservation and taxonomy}

Poor taxonomy can compromise conservation management. Avise and Nelson (1988) showed several instances where faulty taxonomy has resulted in wellintentioned, but misdirected, efforts in endangered species management. An example of inconsistent conservation strategies for endangered New Zealand 


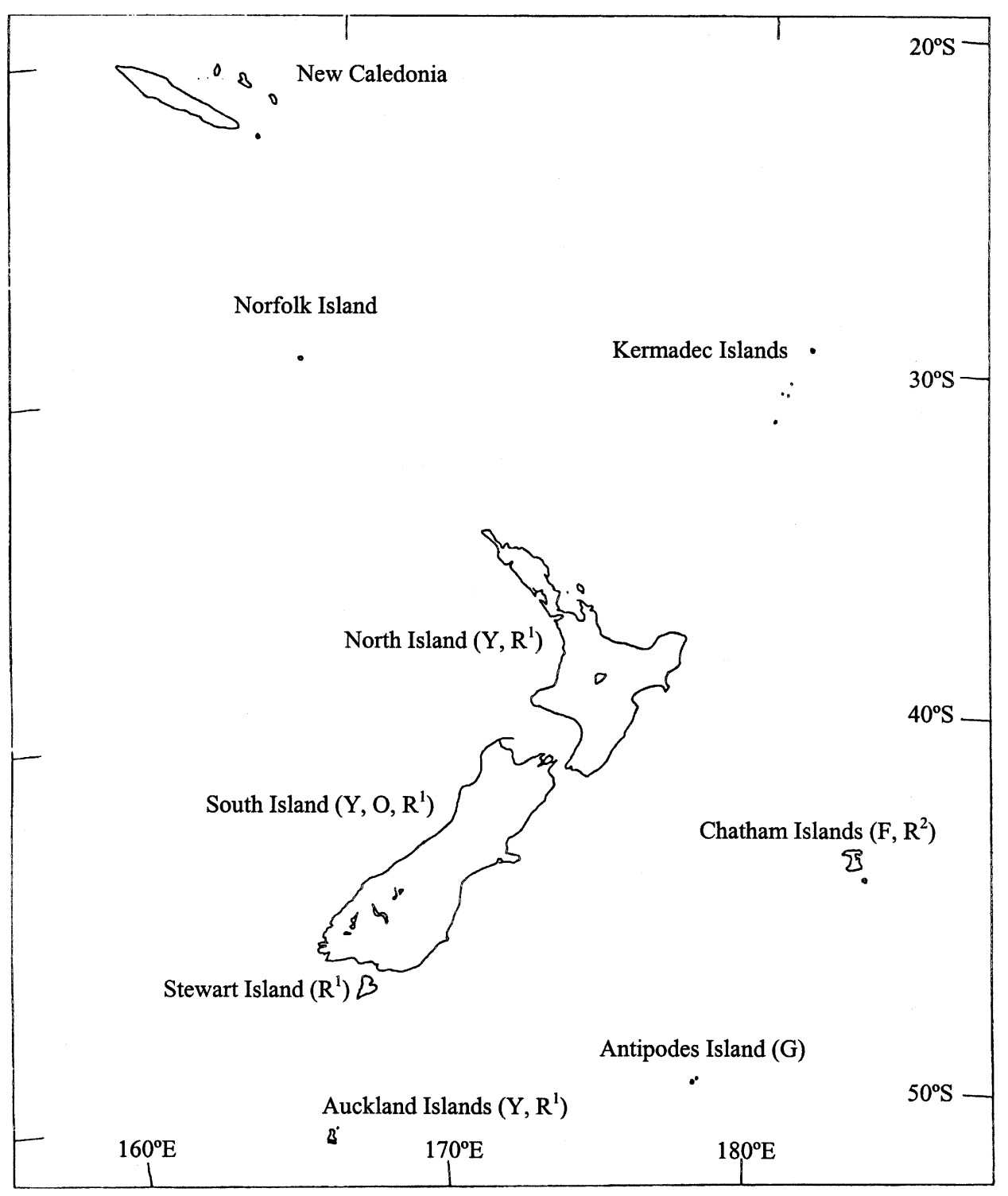

Figure 1. Distribution of Cyanoramphus parakeets examined in this study. G, Antipodes Island (Green) Parakeet C. unicolor; O, Orange-fronted Parakeet C. malherbi; Y, Yellowcrowned Parakeet $C$. auriceps; F, Forbes' Parakeet $C$. forbesi; $R^{1}$, New Zealand Red-crowned Parakeet $C$. novaezelandiae novaezelandiae; $\mathrm{R}^{2}$, Chatham Island Red-crowned Parakeet $C$. $n$. chathamensis.

parakeets is exemplified by the intense management of Forbes' Parakeet, which was officially classified as a subspecies, while the Orange-fronted Parakeet, which is a species (Triggs and Daugherty 1996), has not received anywhere near the same level of attention. There were other extenuating circumstances affecting the unequal level of attention both species received, the most prominent being 
Table 1. Species and subspecies of Cyanoramphus parakeets (Higgins 1999, Forshaw 1989, Taylor 1985)

\begin{tabular}{ll}
\hline Common name & Scientific name \\
\hline Antipodes Island (Green) Parakeet & C. unicolor \\
Orange-fronted Parakeet & C. malherbi \\
Yellow-crowned Parakeet & C. auriceps \\
Forbes' Parakeet & C. forbesi \\
Red-crowned Parakeet & C. novaezelandiae novaezelandiae \\
Chatham Island Red-crowned Parakeet & C. n. chathamensis \\
Reischek's Parakeet & C. n. hochstetteri \\
Kermadec Parakeet & C. n. cyanurus \\
New Caledonia Red-crowned Parakeet & C. n. saisetti \\
Norfolk Island Red-crowned Parakeet & C. n. cooki \\
Lord Howe Island Red-crowned Parakeet (extinct) & C. n. subflavescens \\
Macquarie Island Red-crowned Parakeet (extinct) & C.n. erythrotis \\
Black-fronted Parakeet (extinct) & C. zelandicus \\
Society Parakeet (extinct) & C. ulietanus \\
\hline
\end{tabular}

the difficulty in locating and identifying Orange-fronted Parakeets. When good taxonomic data are available, they should always form the basis upon which conservation decisions are based, and molecular genetic information should be an integral part of such data, wherever possible. As shown above, the comparatively inconsistent management of Forbes' and Orange-fronted Parakeets is a direct result of the lack of detailed genetic information on which to base decisions.

\section{History of Orange-fronted Parakeet}

The Orange-fronted Parakeet has had a complex taxonomic history since the mid-180os (Harrison 1970). It was formally described by Souance (1857) as Cyanoramphus malherbi and later as Platycercus malherbi by Gray (1862) and as the young of Platycercus auriceps by Finsch (1869). Buller (1869) described it as the Alpine Parrot Platycercus alpinus. It was known by this name until Salvadori (1891) synonymized Buller's name for the species with that first given by Souance. From then on, it was considered a separate species as C. malherbi (Oliver 1930, 1955, Falla et al. 1966). Harrison (1970) reviewed its full history and again supported Souance's original classification of the Orange-fronted Parakeet as a species on its own.

Since then, the specific status of the Orange-fronted Parakeet has been the subject of continual debate. Based on morphology and limited field observations, Holyoak (1974) considered the Orange-fronted Parakeet a colour morph of sympatric Yellow-crowned Parakeets C. auriceps. This was supported by preliminary morphological data (Nixon 1981) and captive breeding experiments (Taylor et al. 1986). However, based on their allozyme electrophoresis data, Triggs and Daugherty (1996) questioned the "colour-morph" hypothesis by showing the Orangefronted Parakeet to be genetically well differentiated from both sympatric and geographically distant South Island Yellow-crowned Parakeets. These taxa showed about the same level of differentiation as was found among wellaccepted subspecies of Red-crowned Parakeets C. novaezelandiae (Nei's $D=0.008$ ). Triggs and Daugherty (1996) also concluded that the Orange-fronted Parakeet 
was the sister taxon of Yellow-crowned Parakeet. However, Taylor (1998) again disputed that there are any significant morphometric differences or reproductive isolation between sympatric Orange-fronted and Yellow-crowned Parakeets from Lake Sumner Forest Park, New Zealand.

\section{History of Forbes' Parakeet}

Forbes' Parakeet was first described by Rothschild (1893) as a distinct species $C$. forbesi but was later relegated to subspecies C. a. forbesi of the Yellow-crowned Parakeet C. auriceps by Oliver (1930) without justification. Morphological studies showed Forbes' Parakeet to be larger than Yellow-crowned Parakeets (Fleming 1939, Nixon 1982). Markedly differing vocal repertoires were also observed by Pickard (1990). Based on their allozyme data, Triggs and Daugherty (1996) found that Forbes' Parakeet is genetically very divergent (Nei's $D=0.05$ ) from all Yellow-crowned Parakeets and should be considered a separate species.

\section{Experimental strategy}

In this paper, we test existing taxonomic hypotheses for two species of the genus Cyanoramphus based on detailed analyses of mitochondrial cytochrome $b$ gene $(1,140 \mathrm{nt})$ and control region (1,577-1,582 nt) DNA sequences. The rapid rate of evolution, almost complete lack of recombination and predominantly maternal mode of inheritance of mitochondrial DNA (Gyllensten et al. 1991, Lansman et al. 1983) make reconstructing the phylogenetic history of mitochondrial genes simpler than for nuclear markers. We also carried out field observations in the south branch of the Hurunui Valley (1996-1999) to look for mixed pairs of Yellow-crowned and Orange-fronted Parakeets as a direct test for interbreeding between these two types. The hypotheses tested are as follows.

\section{Hypothesis 1}

That the Orange-fronted Parakeet is a colour morph of sympatric Yellowcrowned Parakeet (Holyoak 1974, Taylor et al. 1986, Taylor 1998) and does not itself constitute a separate species. This view would be supported if, and only if, (a) there is no diagnostic genetic differentiation between the two forms and (b) mixed breeding pairs occur in the wild. Contrary findings would support specific recognition of the Orange-fronted Parakeet as C. malherbi under the phylogenetic, biological, cohesion and recognition concepts of species.

\section{Hypothesis 2}

That the Orange-fronted Parakeet is the sister taxon of Yellow-crowned Parakeet (Triggs and Daugherty 1996). Finding that they are the sister group to another clade of Cyanoramphus parakeets based on analysis of DNA sequence would falsify this hypothesis and strongly support its specific status based on the phylogenetic species concept. 


\section{Hypothesis 3}

That Forbes' Parakeet is sufficiently genetically distinct from Yellow-crowned Parakeet to merit full species recognition under the phylogenetic species concept, as proposed by Triggs and Daugherty (1996).

\section{Methods}

Seventeen individuals of Cyanoramphus parakeets were examined in this study. They represent nine different populations and six taxa (Table 2). All biological samples were in the form of frozen red blood cells and up to 2,722 nt of DNA sequence data were collected per individual for phylogenetic analyses. The cytochrome $b$ gene was sequenced in nine individuals as a preliminary study in order to determine the suitability of this target for resolving the phylogenetics of the taxa in question. Based on these results, the control region was judged to be a superior locus for this purpose. Detailed molecular phylogenetic analysis of all 17 individuals was then carried out using the control region as a target.

\section{DNA extraction}

For DNA preparations, $10 \mu \mathrm{l}$ of red blood cells were added to $500 \mu \mathrm{l}$ of RSB buffer (10 $\mathrm{mM}$ Tris $\mathrm{HCl} \mathrm{pH} \mathrm{7.4,10} \mathrm{mM} \mathrm{NaCl}, 25 \mathrm{mM}$ ethylenediamine tetraacetic acid (EDTA), and lysed by the addition of sodium dodecyl sulphate (SDS) and proteinase K (Life Technologies). The digest was extracted with phenol/chloroform mixtures, and washed in a microconcentrator (Amicon) with sterile microfiltered water and concentrated to $100 \mu \mathrm{l}$ final volume in TE $\mathrm{pH} 8.0$ solution (10 $\mathrm{mM}$ Tris pH 8.0, 0.1 mM EDTA $\mathrm{pH}$ 8.0) and stored at $-80^{\circ} \mathrm{C}$ until required (Sambrook et al. 1989).

\section{Polymerase chain reaction}

Cytochrome $b$ Two partially overlapping segments 477 and $932 \mathrm{nt}$ of the cytochrome $b$ gene were amplified via the polymerase chain reaction (PCR) using primer pairs L14827 (Helm-Bychowski and Cracraft 1993)/H15305 (G.K.C., unpublished) and L15132 (modified from primer CB II, Dawson 1992)/H16065 (modified from primer no. $15915 \mathrm{R}$, Irwin et al. 1991) respectively (Table 3). Together, the two segments cover the complete 1,140 nt cytochrome $b$ gene and part of the tRNA ${ }^{\mathrm{Thr}}$ and ND5 genes flanking cytochrome $b$ (Figure 2). Additional short (317 nt) DNA sequences between the primer pair L14987/H15305 were obtained for individuals FT3304, FT3305, FT3308, and FT3315 (Tables 4a, b). The cytochrome $b$ gene was PCR amplified using aliquots $(4 \mu \mathrm{l})$ of each purified DNA solution as template in a $100 \mu \mathrm{l}$ reaction mixture: $0.5 \mu \mathrm{M}$ each primer, $125 \mu \mathrm{M}$ deoxynucleotide triphosphates (dNTPs), 5 units Taq DNA polymerase (Life Technologies), $1.5 \mathrm{mM} \mathrm{MgCl}$, $10 \mu \mathrm{l}$ 10x Taq buffer, made up to $100 \mu \mathrm{l}$ with sterile microfiltered water and overlaid with mineral oil. Thermal cycling was performed in a Perkin-Elmer model 480 machine, with an initial denaturation step at $95{ }^{\circ} \mathrm{C}$ for 3 mins, followed by 35 cycles of denaturation at $95{ }^{\circ} \mathrm{C}$ for $40 \mathrm{~s}$, 
Table 2. Catalogue of Cyanoramphus parakeet samples analysed in this study

\begin{tabular}{|c|c|c|c|}
\hline Common name & $\begin{array}{l}\text { Taxon as } \\
\text { recognized in } \\
\text { this study }\end{array}$ & $\begin{array}{l}\text { Collection } \\
\text { number(s) }\end{array}$ & Locality \\
\hline $\begin{array}{l}\text { Antipodes Island (Green) } \\
\text { Parakeet }\end{array}$ & C. unicolor & CD1130 & Antipodes Island \\
\hline \multirow[t]{3}{*}{ Red-crowned Parakeet } & \multirow[t]{3}{*}{$\begin{array}{l}\text { C. } n \text {. } \\
\text { novaezelandiae }\end{array}$} & CD1212 & $\begin{array}{l}\text { Nga Manu Wildlife Sanctuary, } \\
\text { southern North Island (Captive) }\end{array}$ \\
\hline & & *FT1016 & $\begin{array}{l}\text { Little Barrier Island, northern North } \\
\text { Island }\end{array}$ \\
\hline & & ${ }^{*} \mathrm{CD} 2035$ & $\begin{array}{l}\text { Poor Knights Island, northern North } \\
\text { Island }\end{array}$ \\
\hline \multirow[t]{2}{*}{$\begin{array}{l}\text { Chatham Island } \\
\text { Red-crowned Parakeet }\end{array}$} & \multirow[t]{2}{*}{$\begin{array}{l}\text { C. } n \text {. } \\
\text { chathamensis }\end{array}$} & $\mathrm{PK} 23$ & $\begin{array}{l}\text { Mangere Island, Chatham Islands; east } \\
\text { of N.Z. mainland }\end{array}$ \\
\hline & & ${ }^{*} \mathrm{CD}_{18} 88$ & $\begin{array}{l}\text { South East Island, Chatham Islands; } \\
\text { east of N.Z. mainland }\end{array}$ \\
\hline Forbes' Parakeet & C. forbesi & CD1814 & $\begin{array}{l}\text { Mangere Island, Chatham Islands; east } \\
\text { of N.Z. mainland }\end{array}$ \\
\hline \multirow[t]{6}{*}{ Yellow-crowned Parakeet } & \multirow[t]{6}{*}{ C. auriceps } & *FT1029 & $\begin{array}{l}\text { Little Barrier Island, northern North } \\
\text { Island }\end{array}$ \\
\hline & & $\mathrm{CD} 1878$ & $\begin{array}{l}\text { Chetwode Islands, northern South } \\
\text { Island }\end{array}$ \\
\hline & & WG168 & $\begin{array}{l}\text { Eglinton Valley, Fiordland National } \\
\text { Park, South Island }\end{array}$ \\
\hline & & $\mathrm{FT}_{3303 /}$ & South branch Hurunui Valley, Lake \\
\hline & & $3304 / 3305$ & Sumner Forest Park, South Island \\
\hline & & $\mathrm{FT}_{3308}$ & $\begin{array}{l}\text { Hawdon Valley, Arthur's Pass National } \\
\text { Park, South Island }\end{array}$ \\
\hline \multirow[t]{2}{*}{ Orange-fronted Parakeet } & \multirow[t]{2}{*}{ C. malherbi } & FT3314/ & South branch Hurunui Valley, Lake \\
\hline & & $3315 / 3316$ & Sumner Forest Park, South Island \\
\hline
\end{tabular}

All blood samples and DNA extracts are held in the Institute for Molecular Systematics, School of Biological Sciences, Victoria University of Wellington, New Zealand. Asterisks indicate specimens excluded from cytochrome $b$ analysis. Collection numbers refer to individual parakeets. Individual CD1212 is morphologically a Red-crowned Parakeet but may have a hybrid origin (Red-crowned $x$ Yellow-crowned Parakeets). The genealogical history of individual CD1212 is unknown, therefore in the context of this study it is referred to as the "captive CD1212 Red-crowned Parakeet".

annealing at $55{ }^{\circ} \mathrm{C}$ for $40 \mathrm{~s}$ and extension at $72{ }^{\circ} \mathrm{C}$ for $60 \mathrm{~s}$ and terminated by a final extension step for 10 mins at $72{ }^{\circ} \mathrm{C}$.

Control region A $2.5 \mathrm{~kb}$ segment of the Cyanoramphus mitochondrial genome was amplified using primer pair L16518/H180o (Table 3) for all individuals (Table 2). This segment is flanked by the $3^{\prime}$ end of the ND6 gene and $5^{\prime}$ end of $12 S$ rRNA gene and encompasses the entire control region, plus tRNA ${ }^{\text {Phe }}$ and $t R N A^{\text {Glu }}$. To amplify the $2.5 \mathrm{~kb}$ segment, PCR were performed as above using $8 \mu \mathrm{l}$ of each purified DNA solution using a reaction mix: $0.5 \mu \mathrm{M}$ each primer, $100 \mu \mathrm{M}$ dNTPs, 5.25 units Expand ${ }^{\mathrm{TM}}$ high fidelity (HF) DNA polymerase enzyme mix (Roche), 1o $\mu \mathrm{l}$ 10× Expand ${ }^{\mathrm{TM}} \mathrm{HF}$ buffer with $15 \mathrm{mM} \mathrm{MgCl}_{2}$ (Roche), made up to $100 \mu \mathrm{l}$ with sterile microfiltered water. A modified amplification protocol was used consisting of denaturation at $95{ }^{\circ} \mathrm{C}$ for 3 mins, followed by 35 cycles of denaturation at $95{ }^{\circ} \mathrm{C}$ for $15 \mathrm{~s}$, annealing at $55{ }^{\circ} \mathrm{C}$ for $30 \mathrm{~s}$ and extension at $68{ }^{\circ} \mathrm{C}$ for 2 
Table 3. Primers used for polymerase chain reaction (PCR) amplification and cycle sequencing

\begin{tabular}{ll}
\hline Primer name & Primer sequence $\left(5^{\prime}\right.$ to $\left.3^{\prime}\right)$ \\
\hline L70-90 (a) & GTA CGT CAC GGG CTC TTT TAG TCC \\
L70-90 (b) & GTC ACG GGC TCT TTT AGT CCT TTA TGG \\
L90-110 & AAC TTC ACG CCC TCG GAT AGA ATA \\
L531 & TGC TCT TTT GTG CCT CTG GTT CCT C \\
L650 & AGC GCC TTG TCT CTG TTG G \\
L14827 & CCA CAC TCC ACA CAG GCC TAA TTA A \\
L14987 & CCC CTC AAA TAT CTC CAT ATG ATG \\
L15132 & CGA ACC GTA CAA TAC GGA TGG YTA ATC \\
L15643 & CTA CCC TAG CCC TCT TCT CAC CCA ACC TAC \\
L16518 & GAC GGG AAT AAA CAA AAA CCA CCA ACA \\
H100-200 & GAC TGA AGT GAG ACT ATT CCT TGA GAC \\
H519 & ATG CGA CTT GAC CGA GGA ACC AGA GG \\
H646 & GGC TAC CCA GAG AAA AAA AAC CAA C \\
H1529 & TGG CTG GCA CAA GAT TTA CCG \\
H1800 & CCC CCG TTT GTG CTC GTA GTT CTC \\
H15163 & GGC GAT GTG GAG GTC GAT GCA GAT GAA GAA \\
H15305 & AAA CTG CAG CCC CTC AGA ATG ATA TTT \\
H15706 & GGC AAA TAG GAA RTA TCA TTC \\
H15977 & AGA TGA TGG GGA ATA GGA TTA GGA TGA \\
H16065 & TCA TCT CCG GTT TAC AAG AC \\
\hline
\end{tabular}

The letters $(\mathrm{L})$ and $(\mathrm{H})$ refer to the light and heavy strands of the mitochondrial genome and numbers to the $3^{\prime}$ nucleotide of the primer relative to the chicken mitochonrdrial DNA sequence (Desjardins and Morais 1990). Some primers used do not align well with the chicken mitochondrial DNA sequence, thus a range of nucleotide positions is given instead of absolute positions.

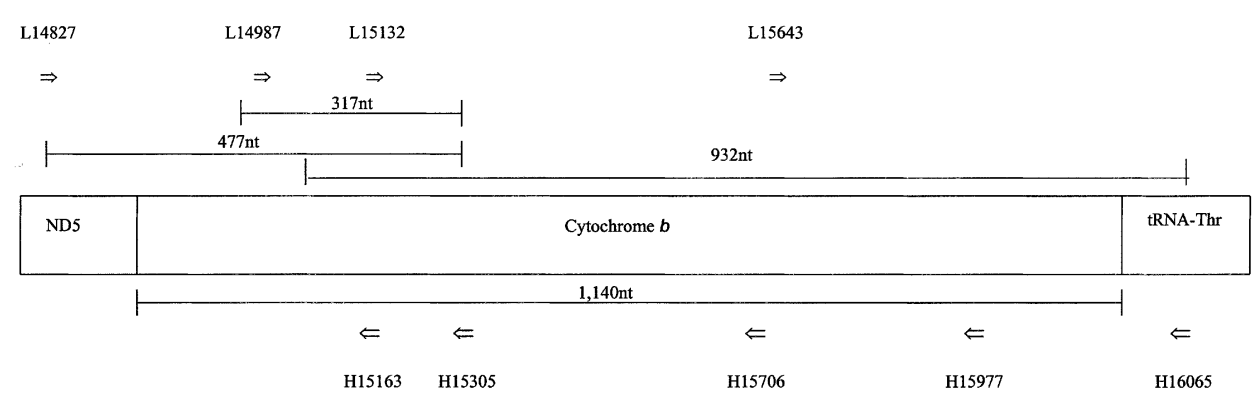

Figure 2. Strategy for polymerase chain reaction (PCR) amplification and cycle sequencing of the cytochrome $b$ genes. Arrows denote primers and their orientation. The numbers refer to their positions relative to the chicken mitochondrial DNA sequence (Desjardins and Morais 1990) and letters to the "light" and "heavy" strands of the mitochondrial DNA (Table 3). We have confirmed that the gene order for Cyanoramphus matches the chicken gene order by sequencing of long-PCR $(5.6 \mathrm{~kb})$ product (data not included in this study). Conserved sequence blocks C, D and CSB-1 (see Baker and Marshall 1997, Mindell et al. 1998) were also found within the control region sequences obtained. The bars above show the location of fragments amplified and that below, the overlapping region of sequence included in analysis. The sizes of gene targets are not drawn to scale. 
Table 4a. DNA sequence divergence of mitochondrial cytochrome $b$ gene and control region between Cyanoramphus parakeet species: table o transversion substitutions

\begin{tabular}{|c|c|c|c|c|c|c|c|c|c|c|c|c|c|c|c|}
\hline & \multicolumn{3}{|c|}{ Orange-fronted } & \multicolumn{7}{|c|}{ Yellow-crowned } & \multicolumn{5}{|c|}{ Red-crowned } \\
\hline & $\begin{array}{l}\text { FT } 3314 \\
\text { Hurunui }\end{array}$ & $\begin{array}{l}\mathrm{FT}_{3315} \\
\text { Hurunui }\end{array}$ & $\begin{array}{l}\text { FT3316 } \\
\text { Hurunui }\end{array}$ & $\begin{array}{l}\mathrm{FT}_{3303} \\
\text { Hurunui }\end{array}$ & $\begin{array}{l}\mathrm{FT}_{3304} \\
\text { Hurunui }\end{array}$ & $\begin{array}{l}\mathrm{FT}_{3305} \\
\text { Hurunui }\end{array}$ & $\begin{array}{l}\mathrm{FT}_{3308} \\
\text { Hawdon }\end{array}$ & $\begin{array}{l}\text { WG168 } \\
\text { Eglinton }\end{array}$ & $\begin{array}{l}\text { CD1878 } \\
\text { Chet- } \\
\text { wodes }\end{array}$ & $\begin{array}{l}\text { FT1029 } \\
\text { Little } \\
\text { Barrier }\end{array}$ & $\begin{array}{l}\text { CD2035 } \\
\text { Poor } \\
\text { Knights }\end{array}$ & $\begin{array}{l}\text { CD1838 } \\
\text { South } \\
\text { East }\end{array}$ & $\begin{array}{l}\text { FT1016 } \\
\text { Little } \\
\text { Barrier }\end{array}$ & $\begin{array}{l}\mathrm{PK}_{23} \\
\text { Mangere }\end{array}$ & $\begin{array}{l}\text { CD1212 } \\
\text { Cap- } \\
\text { tive }\end{array}$ \\
\hline $\mathrm{FT}_{3314}$ & & $0 / 1$ & $0 / 1$ & $42 / 2$ & $40 / 3$ & $40 / 4$ & $43 / 3$ & $40 / 2$ & $47 / 2$ & $43 / 2$ & $34 / 2$ & $33 / 0$ & $32 / 1$ & $31 / 2$ & $41 / 6$ \\
\hline $\mathrm{FT}_{3315}$ & o/o & & o/o & $42 / 1$ & $40 / 4$ & $40 / 5$ & $43 / 2$ & $40 / 1$ & $47 / 1$ & $43 / 1$ & $34 / 1$ & $33 / 1$ & $32 / 0$ & $31 / 1$ & $41 / 7$ \\
\hline $\mathrm{FT}_{3316}$ & $\mathrm{o} / \mathrm{o}$ & o/o & & $42 / 1$ & $40 / 4$ & $40 / 5$ & $43 / 2$ & $40 / 1$ & $47 / 1$ & $43 / 1$ & $34 / 1$ & $33 / 1$ & $32 / 0$ & $31 / 1$ & $4^{1 / 7}$ \\
\hline $\mathrm{FT}_{3303}$ & $4 / 0$ & $2 / 0$ & $4 / 0$ & & $12 / 3$ & $12 / 4$ & $11 / 1$ & $10 / 0$ & $15 / 0$ & $11 / 0$ & $44 / 2$ & $47 / 2$ & $46 / 1$ & $45 / 2$ & $47 / 8$ \\
\hline $\mathrm{FT}_{3304}$ & $2 / 0$ & $2 / 0$ & $2 / 0$ & o/o & & $0 / 3$ & $10 / 4$ & $7 / 3$ & $10 / 3$ & $11 / 3$ & $43 / 5$ & $44 / 3$ & $43 / 4$ & $42 / 5$ & $47 / 9$ \\
\hline $\mathrm{FT}_{3305}$ & $2 / 0$ & $2 / 0$ & $2 / 0$ & o/o & o/o & & $10 / 5$ & $7 / 4$ & $10 / 4$ & $11 / 4$ & $43 / 6$ & $44 / 4$ & $43 / 5$ & $42 / 6$ & $47 / 10$ \\
\hline $\mathrm{FT}_{3308}$ & $1 / 0$ & $1 / 0$ & $1 / 0$ & $1 / 0$ & $1 / 0$ & $1 / 0$ & & $7 / 1$ & $12 / 1$ & $12 / 1$ & $45 / 3$ & $46 / 3$ & $43 / 2$ & $44 / 3$ & $48 / 9$ \\
\hline WG168 & $4 / 0$ & $1 / 0$ & $4 / 0$ & $2 / 0$ & $1 / 0$ & $1 / 0$ & o/o & & 9/o & 9/o & $44 / 2$ & $45 / 2$ & $44 / 1$ & $43 / 2$ & $45 / 8$ \\
\hline CD1878 & $4 / 0$ & $1 / 0$ & $4 / 0$ & $2 / 0$ & $1 / 0$ & $1 / 0$ & o/o & $2 / 0$ & & $14 / 0$ & $49 / 2$ & $50 / 2$ & $49 / 1$ & $48 / 2$ & $52 / 8$ \\
\hline FT1029 & - & - & - & - & - & - & - & - & - & & $47 / 2$ & $48 / 2$ & $45 / 1$ & $46 / 2$ & $50 / 8$ \\
\hline CD2035 & - & - & - & - & - & - & - & - & - & - & & $19 / 2$ & $15 / 1$ & $17 / 2$ & $33 / 8$ \\
\hline $\mathrm{CD} 1838$ & - & - & - & - & - & - & - & - & - & - & - & & $18 / 1$ & $2 / 2$ & $40 / 6$ \\
\hline FT1016 & - & - & - & - & - & - & - & - & - & - & - & - & & $16 / 1$ & $35 / 7$ \\
\hline $\mathrm{PK}_{23}$ & $2 / 0$ & $1 / 0$ & $2 / 0$ & $2 / 0$ & $1 / 0$ & $1 / 0$ & o/o & $2 / 0$ & $2 / 0$ & - & - & - & - & & $38 / 8$ \\
\hline CD1212 & $4 / 0$ & $2 / 0$ & 4/o & 4/o & $2 / 0$ & $2 / 0$ & $1 / 0$ & 4/o & $4 / 0$ & - & - & - & - & $2 / 0$ & \\
\hline CD1814 & 20/o & $8 / 0$ & $20 / 0$ & $18 / 0$ & $8 / 0$ & $8 / 0$ & $7 / 0$ & $18 / 0$ & $18 / 0$ & - & - & - & - & $18 / 0$ & $20 / 0$ \\
\hline CDi13o & $6 / 0$ & $1 / 0$ & $6 / 0$ & $6 / 0$ & $\mathrm{x} / \mathrm{O}$ & $1 / 0$ & $2 / 0$ & $8 / o$ & $8 / 0$ & - & - & - & - & $6 / 0$ & $8 / 0$ \\
\hline
\end{tabular}

Data for cytochrome $b$ are presented below the diagonal and for control region above the diagonal. The values indicate numbers of transition/transversion (ts/tv) for each comparison made. $\mathrm{V}$ bold refer to comparisons made for $317 \mathrm{nt}$ of the cytochrome $b$ gene only. Complete cytochrome $b$ gene: 1,140 nt. Complete mitochondrial control region: 1,584 nt. 


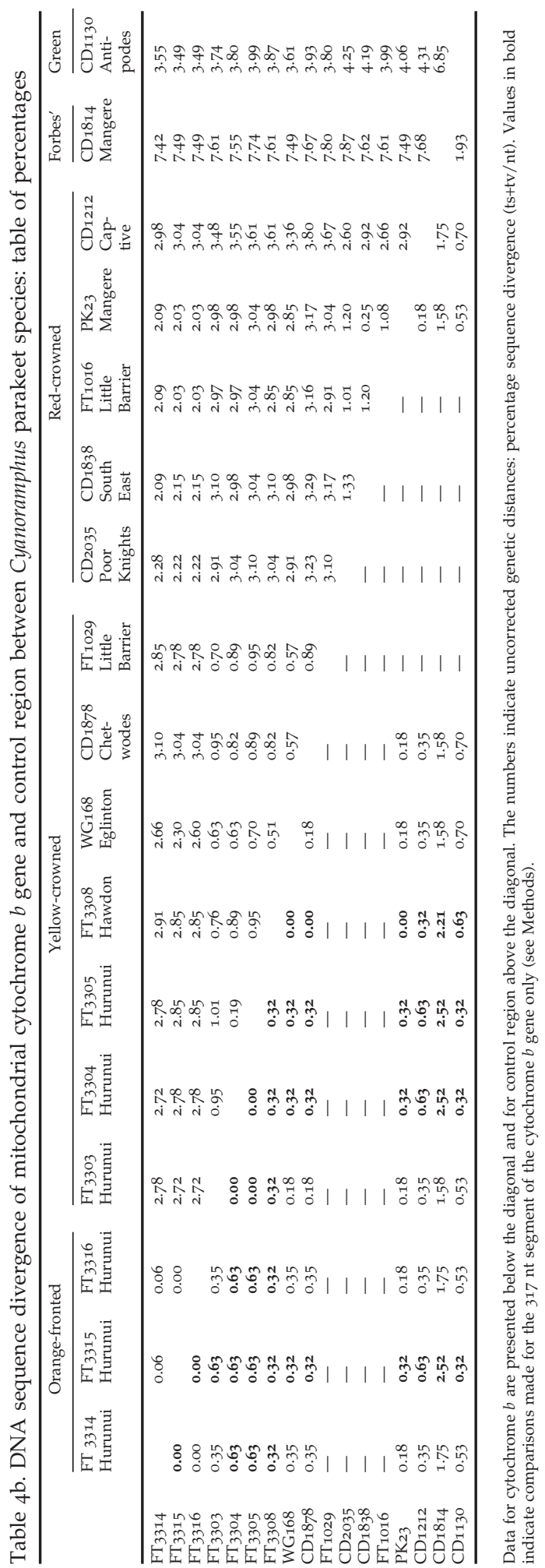


mins. The last 25 cycles had a cumulative increase of extension time of $20 \mathrm{~s} /$ cycle. A final extension step of $68^{\circ} \mathrm{C}$ was carried out for 7 mins after the completion of 35 cycles.

\section{$P C R$ product purification and quantitation}

Double-stranded DNA amplification products were purified on $1 \%$ low-melting agarose gels (FMC Bioproducts) and extracted with a Biorad Prep-A-Gene DNA purification kit. The concentration of purified products was estimated visually following electrophoresis, by comparison with the High DNA Mass ${ }^{\mathrm{TM}}$ ladder (Life Technologies).

\section{DNA sequencing}

Cycle DNA sequencing was performed on purified double-stranded DNA products according to the ABI Prism ${ }^{\circledR}$ Big Dye ${ }^{\mathrm{TM}}$ Terminator Cycle Sequencing Ready Reaction Kit (RR) protocol (Perkin-Elmer 1998) using 40-6o ng template. Sequencing primers used to sequence the cytochrome $b$ gene include the original PCR primers plus H15163 (modified from CB I, Dawson 1992), L14987 (modified from primer no. 14841, Kocher et al. 1989), H15977, L15643 (this study) and H15706 (modified from primer H15547, Edwards et al. 1991). Primers used to sequence the control region segment were L70-90 (a and b), L90-110, L531, L650, L16518, H10o-200, H519, H646 and H1529 (this study; see Table 3). The positions of PCR and sequencing primers are shown relative to the targets and the genes flanking them in Figures 2 and 3. Fluorescently labelled products from cycle sequencing reactions were purified and analysed on an ABI Model 377 Prism ${ }^{\circledR}$ automated DNA sequencer (Perkin-Elmer) according to the protocol mentioned above.

\section{DNA sequence and phylogenetic analyses}

Sequences were obtained from both light and heavy strands of each target region and combined to produce unambiguous contiguous consensus sequence files with DNASTAR's Lasergene 99 data acquisition and analysis package (Anon 1997). Consensus DNA sequences for each individual were aligned with XESEE 3.2 program (Cabot 1998). Sequence statistics were produced and compared using MEGA 1.01 (Kumar et al. 1993).

All phylogenetic analyses were performed using the heuristic algorithm in PAUP* 4.o beta version (Swofford 1998). A maximum parsimony (MP) tree was constructed based on all parsimony informative characters without weighting. Deletions in the sequence data are treated as a fifth character state. Maximum likelihood (ML) and minimum evolution (ME) analyses were carried out based on the General Time Reversible substitution model of Rodríguez et al. (1990) with gamma approximation $(\alpha=0.17)$. Bootstrap resampling (Felsenstein 1985) was carried out to provide an assessment of support for Cyanoramphus clades identified from control region sequences (MP 5,000 replicates, ML 300 replicates, ME 1,00o replicates). 


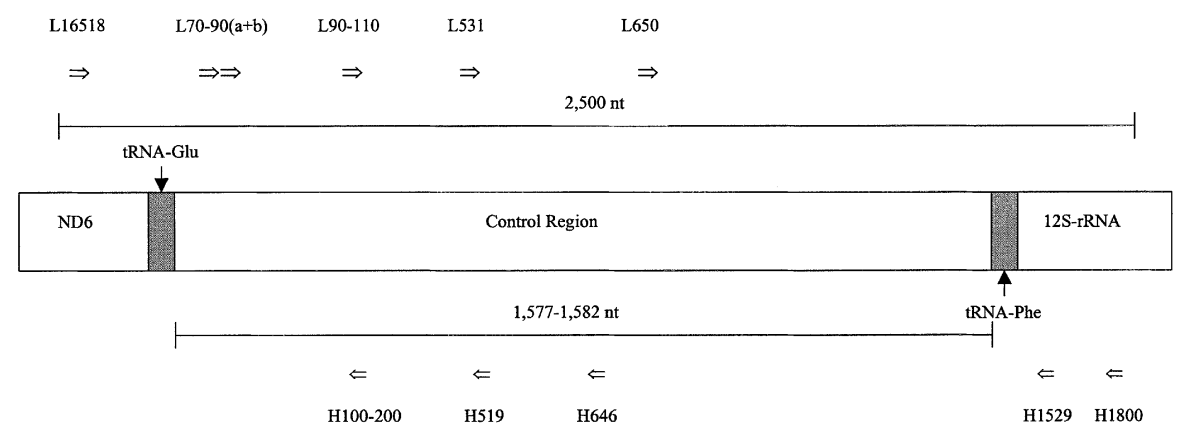

Figure 3. Strategy for PCR amplification and cycle sequencing of the mitochondrial control region. Arrows denote primers and their orientation. The numbers refer to their positions relative to the chicken mitochondrial DNA sequence (Desjardins and Morais 1990) and letters to the "light" and "heavy" strands of the mitochondrial DNA (Table 3). We have confirmed that the gene order for Cyanoramphus matches the chicken gene order by sequencing of long-PCR ( $5.6 \mathrm{~kb})$ product (data not included in this study). Conserved sequence blocks C, D and CSB-1 (see Baker and Marshall 1997, Mindell et al. 1998) were also found within the control region sequences obtained. The bar above the genes shows the location of amplified fragment and that below, the region of sequence included in analysis. The sizes of gene targets are not drawn to scale.

\section{Parakeet pairing data collection}

As part of a larger study into the ecological relationships between sympatric Orange-fronted and Yellow-crowned Parakeets in the south branch of the Hurunui Valley (North Canterbury), the occurrence of mixed "pairs" was surveyed in an area of beech Nothofagus spp. forest $(7.5 \times 0.5 \mathrm{~km})$ on the flat section of the valley floor. This constituted approximately $20 \%$ (by area) of the total nesting habitat available to both Yellow-crowned and Orange-fronted Parakeets within the valley. The present estimate of wild Orange-fronted Parakeet numbers indicates less than 500 individuals (Kearvell 1999). They are currently known only to persist in two locations, the south branch of the Hurunui River and the Hawdon River valleys. Recent transect counts have shown that Orange-fronted Parakeets are encountered 10 times more frequently in the south branch of the Hurunui Valley than in the Hawdon Valley (Kearvell 2000). The area surveyed in the former location thus covers a significant proportion of the known Orange-fronted Parakeet population range. Due to the large area involved, the survey site was arbitrarily divided into two approximately equal sections and each surveyed on consecutive days. If the weather was poor, the other section was counted the following day. Counts were carried out during spring and summer, between 13 November 1998 and 24 February 1999, covering 48 days of survey. The forest in this area was homogeneous. This was tested using the forest survey "PointCentre-Quarter" technique (Cottam and Curtis 1956, Greig-Smith 1964).

All positively identified parakeets were given a map coordinate. They were then assessed for pair status. The criterion for assessing whether or not two birds were a pair was designed to identify even the most tentative of examples and thus identify any possible chances that the two species were forming mixed breeding pairs rather than pairing in a strictly assortative manner. The primary 
Table 5. Number of confirmed parakeet pairs in the survey area, south branch Hurunui Valley, New Zealand during the $1998 / 1999$ summer season

\begin{tabular}{lcccc}
\hline Season & $N$ & $\begin{array}{c}\text { Number of confirmed } \\
\text { unique pairs }\end{array}$ & Mixed pairs & $\begin{array}{c}\text { Confirmed } \\
\text { nests }\end{array}$ \\
\hline Orange-fronted Parakeet & 516 & 32 & 0 & 17 \\
Yellow-crowned Parakeet & 570 & 26 & 0 & 13 \\
Totals & 1086 & 58 & 0 & 30 \\
\hline
\end{tabular}

$N$ is the total number of birds recorded over all occasions within field season. $N=$ (number of confirmed unique pairs $\times 2$ ) + solitary birds which have been positively identified either as a Yellow-crowned or Orange-fronted Parakeet + (number of pairs with coordinates which overlapped another pair $\times 2$ ). Mixed pairs is the total number of confirmed interspecific pairs identified. Detailed count data are only given for the 1998/1999 season, using the coordinate method (described in Methods) to avoid counting pairs more than once. Preliminary surveys recorded 9 pairs of Orange-fronted Parakeet $(N=67)$ and 27 pairs of Yellow-crowned Parakeet $(N=161)$ in the 1996/1997 season. The corresponding values were 18 pairs of Orange-fronted $(N=65)$ and 15 pairs of Yellow-crowned Parakeets $(\mathrm{N}=78)$ for the $1997 / 1998$ season. No mixed pairs were recorded in either year. However, since coordinates were not recorded in 1996/1997 and 1997/ 1998 seasons we cannot be certain that some pairs were not counted more than once. In 1998/ 1999, for comparison, 186 pairs of Orange-fronted and 140 pairs of Yellow-crowned Parakeets were originally recorded, but these were reduced to 32 and 26 confirmed unique pairs after coordinate analysis.

criterion for a "pair" was that the two birds in question appeared to be associating together without influence from a third bird (unless one bird was either a fledgling or a nestling or the three birds were all in a situation of aggressive interspecific display) and their behaviour was collaborative (i.e. preening, courting, nest hole inspection, mating, feeding fledglings/nestlings, egg incubation or simply sitting on a branch), not aggressive. Each pair was observed for as long as possible in order to verify their specific status and confirm nonaggressive behaviour. To avoid multiple counting of the same pair, no new pair record was accepted unless it was outside a $100 \mathrm{~m}$ radius from the nearest pair contact and was encountered after more than one minute from the last positive pair record. New Zealand parakeets have non-exclusive home ranges (Elliott $e t$ al. 1996, Greene 1998) and perform most of their breeding behaviour less than 50 $\mathrm{m}$ from their actual/prospective nest site.

The survey was also carried out in the Hurunui Valley during the summer seasons of 1996/1997, 1997/1998. It is important to note that repeat counting of pairs may have occurred during these two seasons because map coordinates were not recorded during these years but were in the 1998/1999 season as described earlier. All data obtained are presented in Table 5.

\section{Results}

The two segments of the mitochondrial cytochrome $b$ gene and the entire control region were readily amplified for most samples. For some samples, optimization of PCR conditions (lowering of annealing temperature to $54{ }^{\circ} \mathrm{C}$ or increasing cycle numbers to a total of 40 ) was required before the desired level of target 
amplification was achieved. In PCR catalysed amplifications, the expected 477/ $932 \mathrm{nt}$ and $2.5 \mathrm{~kb}$ targets were consistently amplified. Slight variation in product size was observed for the $2.5 \mathrm{~kb}$ targets. This is expected, since it includes the mitochondrial control region, which is characterized by its high variability, the occurrence of expanding repeat units, insertions and deletions. Negative control PCR reactions showed no amplification products in any case. All DNA sequence electrophoretograms could be read unambiguously, and data representing almost all nucleotide positions were confirmed by sequencing from both directions or from at least two different primers in the same direction. The acquired DNA sequences for each target for each individual were combined to obtain consensus sequences and these were aligned and compared with consensus sequences of other Cyanoramphus individuals (Figures 4 and 5). The Cyanoramphus cytochrome $b$ sequences aligned well with those published for other Psittaciformes (Birt et al. 1992, Leeton et al. 1994, Miyaki et al. 1998) and for chicken (Desjardins and Morais 1990), alignments are not shown in this report, and form the basis of a wider taxonomic study of the placement of the Cyanoramphus genus within Psittaciformes (Boon et al. unpubl.). Control region sequences could only be aligned with the chicken sequences at highly conserved regions (alignments not shown) and no other parrot mitochondrial control region sequences were available for comparison. The GenBank accession numbers for sequences reported in this paper are $\mathrm{AF} 218735-\mathrm{AF}_{218764}$.

Direct sequencing of PCR products from mitochondrial DNA templates may sometimes yield data that include a mixture of both authentic mitochondrial and nuclear copies of mitochondrial gene sequences leading to single nucleotide ambiguities or more serious artifacts (Smith et al. 1992, Lopez et al. 1994, Sorenson and Fleischer 1996). During our analyses, we examined all of the experimental data for molecular signatures characteristic of mitochondrial DNA genes and their nuclear homologues. Such characteristics include codon-specific pattern of substitutions, lack of stop codons, insertions/deletions, frameshifts or chemically non-conservative amino acid changes in coding regions, high transition: transversion ratio - especially of comparisons between closely related taxa, characteristic among site rate variation and nucleotide frequencies, identification of conserved sequence blocks (e.g. D and C box, CSB- 1 in mitochondrial control region) and the use of highly specific as opposed to "universal" sequencing and PCR primers (Mindell et al. 1998, Norman et al. 1998, Baker and Marshall 1997 and Zhang and Hewitt 1996). In summary, we were satisfied by the above observations that we had obtained authentic mitochondrial DNA sequences in each case and not nuclear insertions of mitochondrial DNA genes or "Numts" (see Quinn 1997 for further general discussion of evidence and comments regarding "Numts"). We have also confirmed that the gene order for Cyanoramphus parakeets matches the chicken Gallus gallus (Mindell et al. 1998, Desjardins and Morais 1990) thus adding a parrot taxon to the group of birds with that particular gene configuration. This was done by sequencing a 5.6-kb-long PCR product (data not included). Supporting this conclusion, PCR primers (L16518 in ND6 gene; H180o in $12 \mathrm{~S}$ rRNA gene), which were designed to amplify the mitochondrial control region produced sequences that had molecular signatures (e.g. motifs $\mathrm{C}, \mathrm{D}$ and CSB-1, see Mindell et al., 1998) characteristic of the target concerned. The data 
presented in this paper include the total number of transitions/transversions (ts/tv) and uncorrected percentage divergence between different taxa compared (Tables $4 \mathrm{a}, \mathrm{b}$ ).

\section{Sequence variation and population differentiation}

Cytochrome $b$ A total of 28 variable sites were identified among the cytochrome $b$ sequences for the nine individuals examined (Figure 4) with 8 at the first codon position, $\mathrm{O}$ at the second and 20 at the third. No insertions or deletions were detected, and all nucleotide substitutions were transitions, suggesting an exceptionally high ts/tv ratio (> 20:1). This pattern is highly characteristic of recently diverged mitochondrial DNA haplotypes (Quinn 1997, Moritz et al. 1987).

The cytochrome $b$ sequences observed are identical for all three Orange-fronted individuals examined whereas intraspecific comparisons within Yellow-crowned Parakeets and Red-crowned Parakeets display sequence variation of $0.18 \%$. All percentages presented in the Results and Discussion of this paper refer to the complete cytochrome $b$. Interspecific comparisons of Orange-fronted and Yellowcrowned Parakeets show a higher level of sequence divergence, around $0.35 \%$, whereas comparisons of Orange-fronted Parakeet with Red-crowned Parakeet cytochrome $b$ sequences show a range of difference from 0.18 to $0.35 \%$. Interspecific comparisons of the Antipodes Island Parakeet C. unicolor with all other species (excluding Forbes' Parakeet) ranged from 0.53 to $0.70 \%$, being much higher than other comparisons (Table $4 \mathrm{~b}$ ). Forbes' Parakeet displayed the highest level of divergence from all other species with a range of 1.58 to $1.70 \%$, well beyond any other interspecific comparison.

Also unique to the Forbes' Parakeet nucleotide sequence were two transitions giving rise to inferred amino acid substitutions at positions 43 (ala for thr) and 307 (leu for phe). Using the Orange-fronted Parakeet cytochrome $b$ protein sequence as reference, a change at amino acid position 53 (ala for thr) was

Figure 4. Variable sites of aligned cytochrome $b$ sequences of 17 Cyanoramphus individuals. Numbers above the sequences indicate the position of the variable site corresponding to positions $1-1,140$ of aligned sequences. Dashes indicate missing data. 
C. malherbi (Hurunui Valley - FT3314) C. malherbi (Hurunui Valley - FT3315)

c. n. novaezelandiae (Poor Knights Is - CD2035)

C. n. novaezelandiae (Little Barrier Is -

c. n. chathamensis (South East Is - CD1838)

c. n. Chathamensis (Mangere Is - PK23)

c. n. hovaezelandiae (Capteve Red - CD1212)

c. auriceps (Hurunui Valley - FT3304)

C. auriceps (Chetwodes Is - CD1878)

c. auriceps (Hawdon Valley - FT3308)

C. auriceps (Eglinton Valley - WG168)

c. auriceps (Little Barrier Is - FT1029)

C. auriceps (Hurunui Valley - FT3303)

c. unicolor (Antipodes Is - CD1130)

c. forbesi (Mangere Is - CD1814)

c. malherbi (Hurunui Valley - FT3314)

c. malherbi (Hurunui valley - FT3315)

c. malherbi (Hurunui valley - FT3316)

c. n. novaezelandiae (Poor Knights Is - CD2035)

C. n. novaezelandiae (Little Barrier Is - FT1016)

c. n. chathamensis (South East Is - CD1838)

c. n. novaezelandiae (Captive Red - CD1212)

C. n. novaezelandiae (Captive Red

c. auriceps (Hurunui Valley - FT3305)

C. auriceps (Chetwodes Is - CD1878)

C. auriceps (Hawdon Valley - FT3308)

C. auriceps (Eglinton Valley - WG168)

C. auriceps (Little Barrier Is - FT1029)

C. auriceps (Hurunui Valley - FT3303)

C. unicolor (Antipodes Is - CD1130)

c. forbesi (Mangere Is - CD1814)
111111111111111111222222222333333333333333333344444444444444444555 7788991233444455677778995666788990112222345556678899011111456667788999001 57806191302056725713699681348747089041457156891613534701237204575612467462 TGTGAACTCCTCCCTCACCGCGTTCTCTTTCTCACTCTTTATCTAGCTGCCGACGTCCCTATCACCGTCACTAC

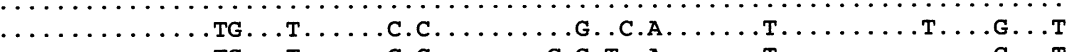

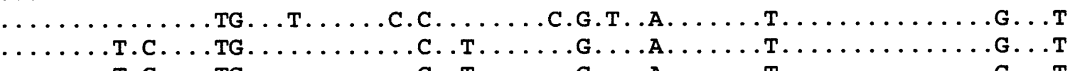

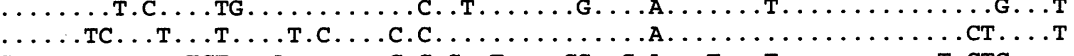

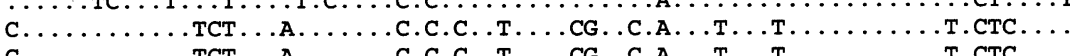

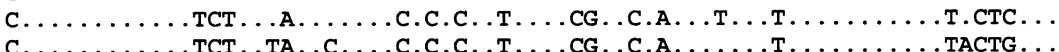

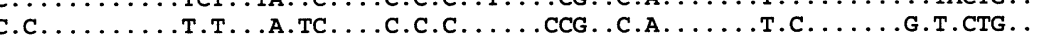

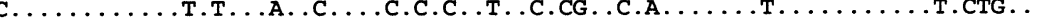

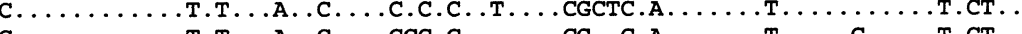

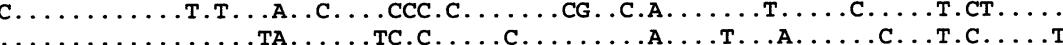

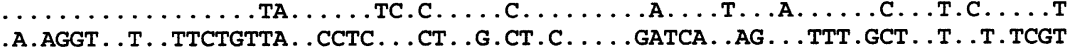
111111111111111 5555555555566666666666666666666666666666666677777777779999990000000000111111 22222788899000011122233333344445555667777792223555566167781334455788012334 23478413559017906912801235901890128890156851349568902603656193967717858019 TCACAGACGCCTCTATCCCTTAAGCTTTGTTCTCGTTTCCAGTATCC-CACAGTTTCCTTAGCTTTTTAACACT

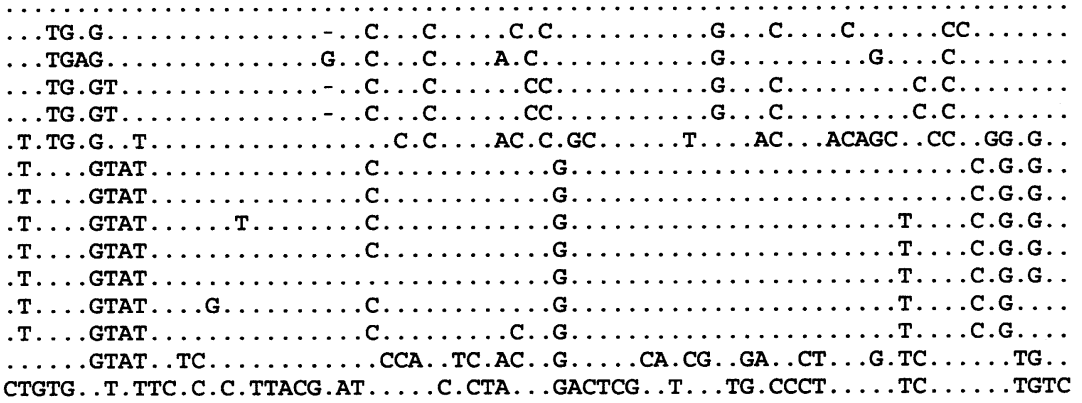

Figure 5. Variable sites of aligned Control Region sequences of 17 Cyanoramphus individuals. Numbers above the sequences indicate the position of the variable site corresponding to positions 1-1,584 of aligned sequences. 
1111111111111111111111111111111111111111111111111111111111 11111111122222222222333333333444444444444445555555555555555 5566777799001234566889001147799012445677778880111112222446777 2924235736577501278092262775879982891824571784035680157080059

TACCTGTTCAATGCCTCGTCTGCTCCTCCTCATTGGCCCCCTCACTCTCATACATCTTACG

C. malherbi (Hurunui Valley - FT3314)

C. malherbi (Hurunui Valley - FT3315)

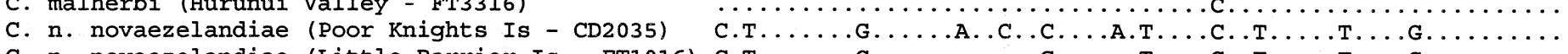

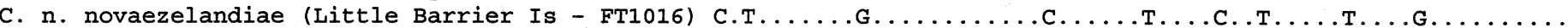

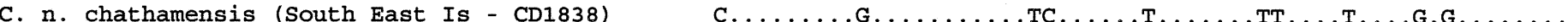

C. n. chathamensis (Mangere Is - PK23)

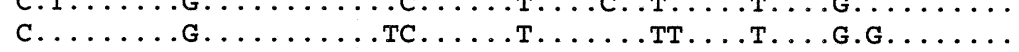

C. n. novaezelandiae (Captive Red - CD1212)

C. auriceps (Hurunui Valley - FT3304)

C. auriceps (Hurunui Valley - FT3305)

C. auriceps (Chetwodes Is - CD1878)

C. auriceps (Hawdon Valley - FT3308)

C. auriceps (Eglinton Valley - WG168)

C. auriceps (Little Barrier Is - FT1029)

C. auriceps (Hurunui Valley - FT3303)

C. unicolor (Antipodes Is - CD1130)

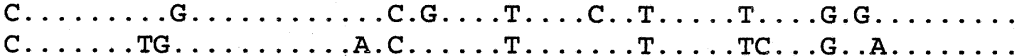

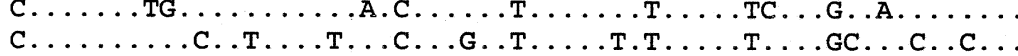

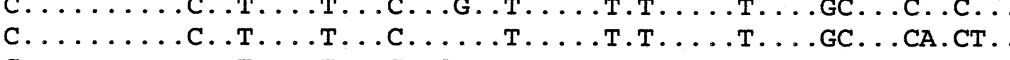
С.......................Ст.T...GT...GC..С..С.T.

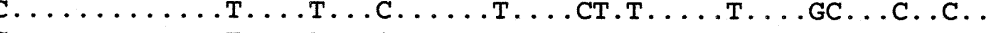

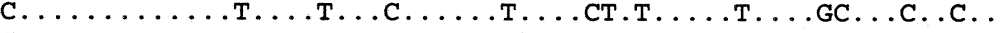

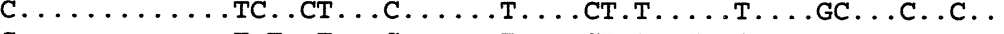

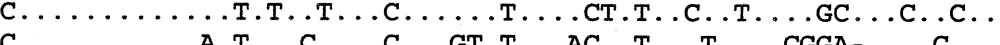

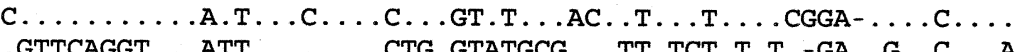

Figure 5. Continued. 
observed for the Antipodes Island Parakeet and at position 361 (thr for ala) for the captive Red-crowned Parakeet.

Control region Of 1,584 sites compared in the Cyanoramphus mitochondrial control region 217 were variable. These provided 91 parsimony informative sites for cladistic analysis. Genetic distances ranging from o to $7.87 \%$ (uncorrected) were observed among the 17 individuals examined. Within species, control region sequences from Orange-fronted Parakeets are very homogenous, with individuals differing at between 0.00 and $0.06 \%$ of sites. The DNA sequences from Yellow-crowned Parakeets displayed higher intraspecific divergence, ranging from 0.19 to $1.01 \%$ between individuals. The highest level of intraspecific divergence observed was between individual Red-crowned Parakeet sequences. Values ranged from $0.25 \%$ in comparisons of DNA sequences within Chatham Island Red-crowned Parakeet populations to $2.92 \%$ in comparisons between Chatham Island Red-crowned Parakeet populations and the captive CD1212 Redcrowned Parakeet (see Table 2 for guide on nomenclature). The low intraspecific divergence for the Orange-fronted Parakeet could be due in part to the limited geographical range of this species.

The control region sequences from the Orange-fronted Parakeets are most similar to those from Little Barrier Island and Mangere Island Red-crowned Parakeets (2.03\% divergence). This level of genetic differentiation is lower than comparisons between mitochondrial control region sequences from Orange-fronted Parakeet and sympatric Yellow-crowned Parakeet individuals (2.72-2.85\%). The levels of genetic divergence between Red and Yellow-crowned Parakeets were close to this and ranged from 2.85 to $3.80 \%$. The sequences from Antipodes Island Parakeet displayed consistently high levels of interspecific divergence paralleling those shown earlier by the cytochrome $b$ data and ranged from 3.49 to $4.25 \%$. Again, Forbes' Parakeet is well differentiated from all other Cyanoramphus species examined in this study. Genetic distances between the single Forbes' Parakeet sequence reported here and others is between 7.49 and $7.80 \%$; i.e. much greater than the values seen in other interspecific comparisons between Cyanoramphus taxa. We note that the sequence presented is representative of the major Forbes' Parakeet mitochondrial DNA haplogroup and have since obtained identical or very closely related (o-17 nt substitutions out of 1573-1577 nt compared) sequences for five further individuals (Boon et al. unpubl.).

\section{Field observations}

A total of 1,086 individual parakeets were positively identified during the 1998/ 1999 survey period. From these, 106 confirmed pair contacts were obtained, which was eventually reduced to 58 unique pairs after analysis of coordinates. No mixed Yellow-crowned/Orange-fronted Parakeet pair was encountered. Sympatric Orange-fronted and Yellow-crowned Parakeets, in the Hurunui Valley, appear to court, mate and nest strictly assortatively (Table 5). During the collection of these data, further pairs were observed undertaking feeding and maintenance behaviour (see legend, Table 5). No mixed pairs were observed within these categories. Yellow-crowned Parakeets have been recorded feeding at considerable distances from nest sites (Elliott et al. 1996), which makes repeat 


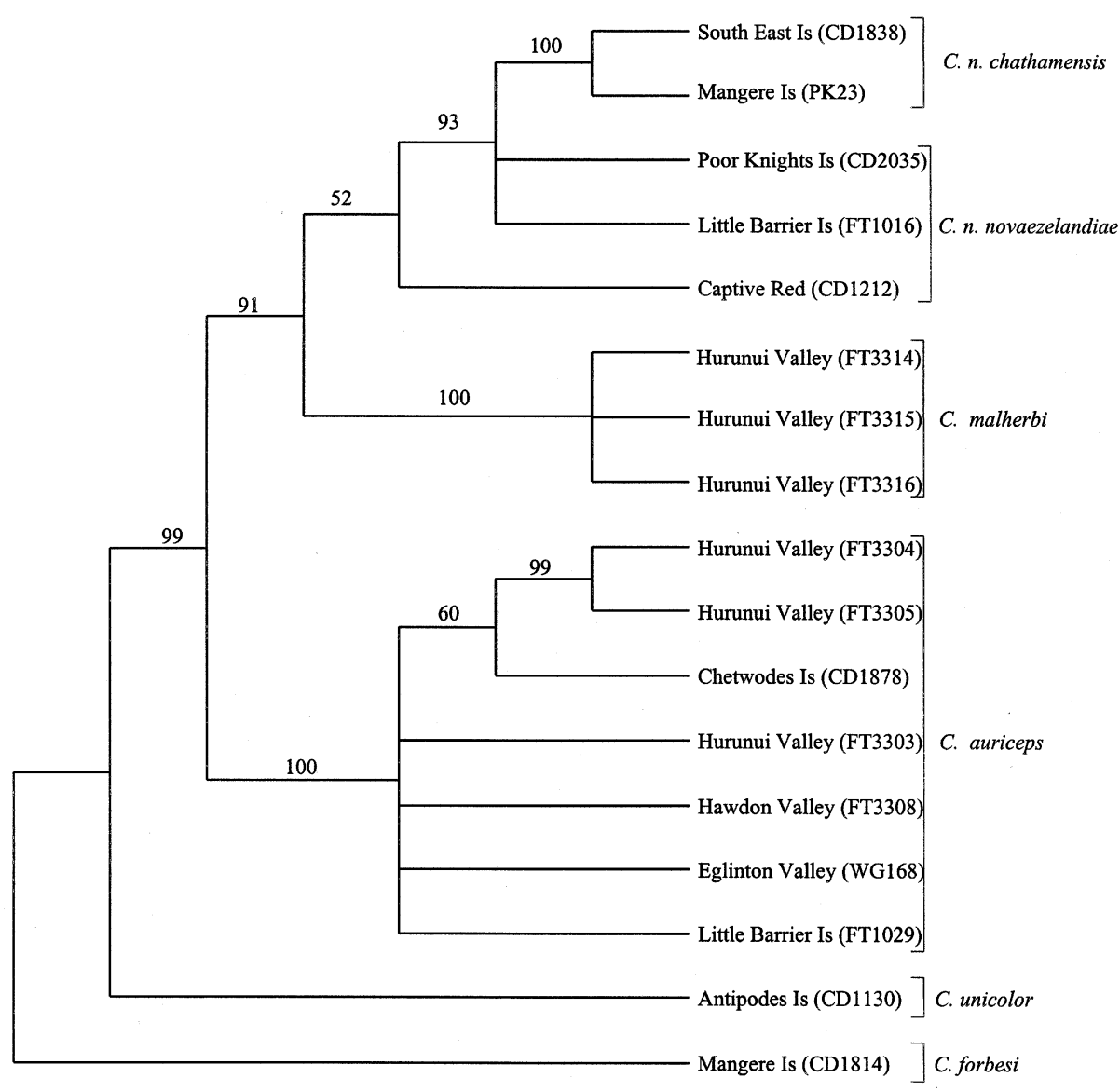

Figure 6. Fifty per cent consensus parsimony tree based on control region sequences for 17 Cyanoramphus individuals. C. forbesi is used as outgroup. Bootstrap values greater than $50 \%$ are indicated at nodes (5,000 replicates).

counting of pairs when feeding much more common than when undertaking breeding behaviour. These pairs have not therefore been reduced using the coordinates.

\section{Phylogenetic analyses}

Evolutionary trees were not constructed using the cytochrome $b$ data due to low numbers of parsimony informative characters ( 5 of 28 variable sites). Nevertheless, the general trends shown by this locus do correspond to those shown by the control region.

Using the control region data, phylogenetic trees were inferred using three independent methods (Figures 6-8). The general topologies are congruent, with only a few minor differences with respect to levels of resolution and bootstrap support achieved. In all analyses, all Orange-fronted Parakeet individuals cluster 


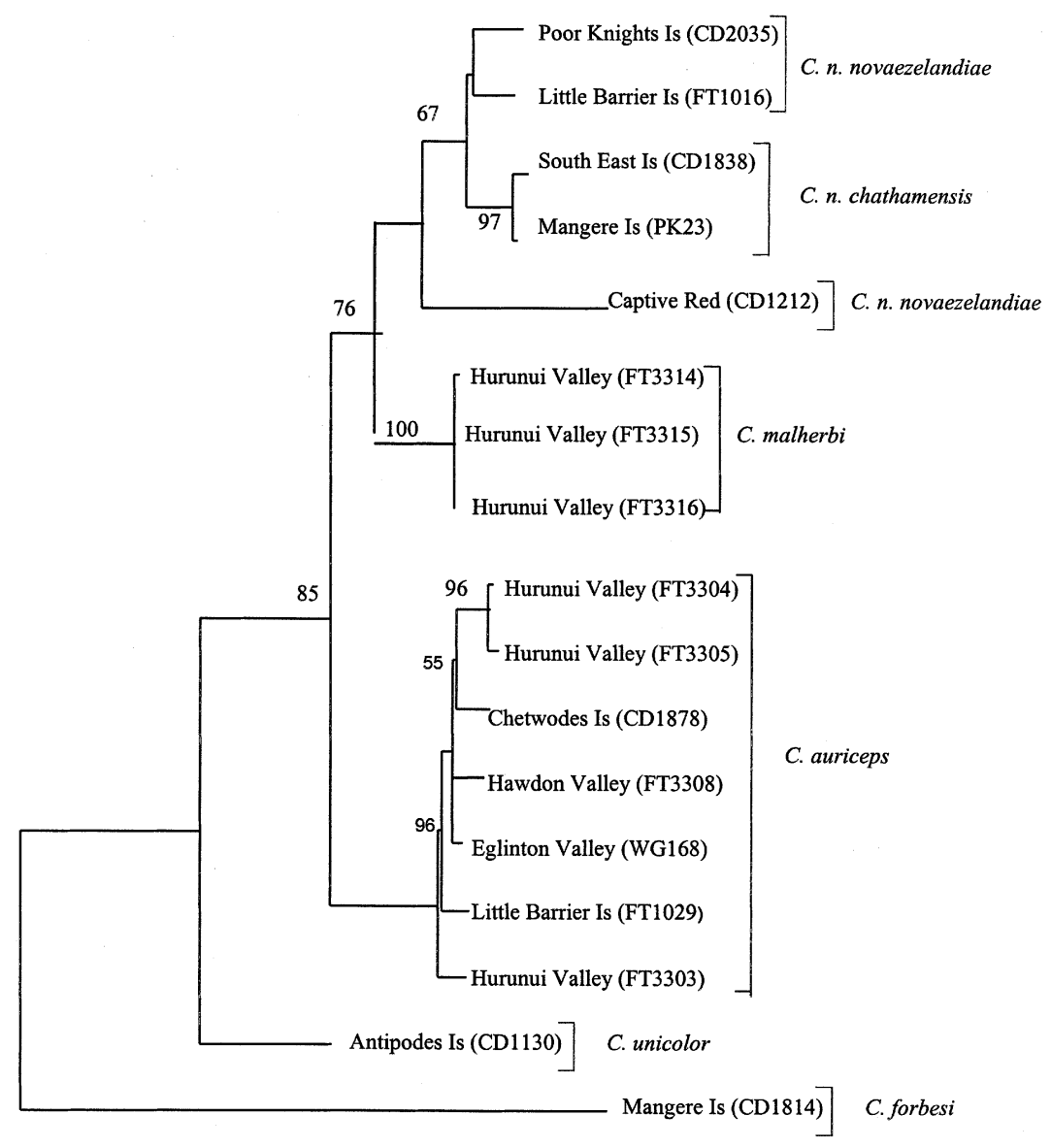

Figure 7. Maximum likelihood tree based on control region data for 17 Cyanoramphus individuals. C. forbesi is used as outgroup. Bootstrap values greater than $50 \%$ are indicated at nodes (300 replicates). The General Time Reversible substitution model (Rodríguez et al. 1990) and gamma approximation $(\alpha=0.17)$ of variable sites were used.

together in a distinct group and they are clearly the sister taxon of the Redcrowned Parakeet rather than Yellow-crowned Parakeet. All of the Yellowcrowned Parakeet individuals group into a single fully supported clade with very little population structure. The Chetwodes Island Yellow-crowned Parakeet appears to be the sister taxa of the Hurunui Valley cluster, in both the Minimum Evolution and Maximum Likelihood trees, but clusters with the Eglinton Valley individual in the Maximum Parsimony tree. The three well-supported and entirely distinct clades comprise Yellow-crowned, Orange-fronted and Redcrowned birds with Antipodes Island Parakeet being a clear outlier and Forbes' Parakeet as the basal taxon. In all analyses, Forbes' Parakeet is clearly genetically differentiated from Yellow-crowned Parakeet. The genetic distances between Forbes' Parakeet and either Red or Yellow-crowned Parakeets are three to four times greater than between Red and Yellow-crowned Parakeets. 


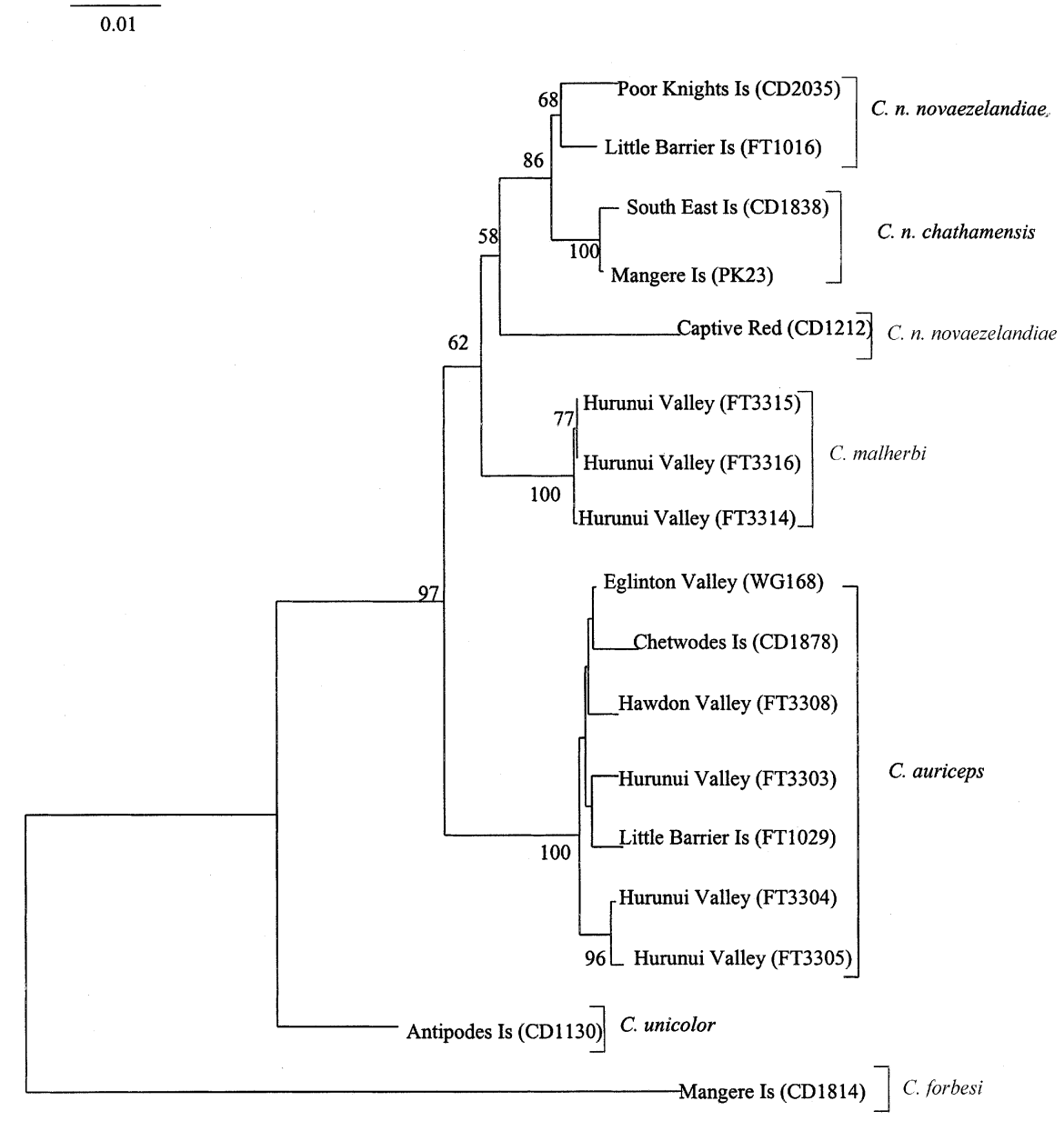

Figure 8. Minimum evolution tree based on control region data for 17 Cyanoramphus individuals. $C$. forbesi is used as outgroup. The General Time Reversible distance (Rodríguez et al. 1990) was used for the minimum evolution tree above $(\alpha=0.17)$. Bootstrap values $(1$, ooo replicates) for branches are indicated by corresponding arrows.

\section{Discussion}

\section{Species concepts}

Determination of species status should be viewed as testing a hypothesis (Simpson 1961, Baum and Shaw 1995) and should be based on the best interpretation of all relevant available evidence (Graybeal 1995). In this study we apply four species concepts to our data, the Biological Species Concept (BSC; Mayr 1942, 1970), the Phylogenetic Species Concept (PSC; Cracraft 1983, 1997), the Recognition Species Concept (RSC; Paterson 1985) and the Cohesion Species Concept (CSC; Templeton 1989).

A "biological species" is a group of interbreeding individuals in a natural 
population that is reproductively isolated from other such groups. A "phylogenetic species" can be uniquely diagnosed and has a parental pattern of ancestry and descent. The latter criterion often refers to the monophyly of the group in question. The RSC defines a species as "the most inclusive population of individual biparental organisms which share a common fertilization system". Lastly, a "cohesion species" is the most inclusive population of individuals having the potential for phenotypic cohesion through intrinsic cohesion mechanisms. Our evidence includes identification of separate gene pools, diagnosability and monophyly of each species and field evidence on mate choice. The genetic and field data obtained satisfy practical criteria under all of the above species concepts for both Orange-fronted and Forbes' Parakeets.

\section{Taxonomic status}

Orange-fronted Parakeet We have found significantly large, distinct, consistent and apparently fixed genetic differences between Orange-fronted Parakeets and the sympatric population of Yellow-crowned Parakeets in the Hurunui Valley. This demonstrates exclusivity of the Orange-fronted Parakeet mitochondrial gene pool. Both synapomorphic (parsimony informative) and autapomorphic (private) characters were observed to differ between Yellow-crowned and Orange-fronted Parakeets. These are diagnostic for species and certainly reveal patterns of ancestry and descent. Based on the level of genetic differentiation and cladistic pattern observed, the Orange-fronted Parakeet forms a readily diagnosable and monophyletic taxon fulfilling the PSC. Based on percentage divergence between mitochondrial control region nucleotide sequences (Tables $4 \mathrm{a}, \mathrm{b}$ ), our data place Orange-fronted Parakeet and sympatric Yellow-crowned Parakeet well beyond the level of interspecific genetic divergence observed between other interspecific comparisons of accepted Cyanoramphus species (Figure 8). Very well-supported (bootstrap value $=91 \%$ ) parsimony analysis placed Red-crowned Parakeet as the sister species of Orange-fronted Parakeet. This finding is contrary to current classifications. We therefore reject Hypothesis 2, thus supporting further the specific status of the Orange-fronted Parakeet.

Field observations in the Hurunui Valley, where the largest known population of Orange-fronted Parakeet exists, indicate strong assortative mating (Table 5). The absence of mixed (Yellow $\times$ Orange) nesting pairs therefore fulfils the practical criterion of reproductive isolation under the BSC as advanced by Mayr (1970). Strongly assortative mating implies separate mate recognition systems for Orange-fronted and Yellow-crowned Parakeets, thereby satisfying the RSC of Paterson (1985). The above observations corroborate the exclusivity of the mitochondrial gene pools displayed by Orange-fronted and Yellow-crowned birds respectively. This indicates the existence of cohesion mechanisms within each of the "species", accommodating the key criterion of the CSC according to Templeton (1989).

These findings dispute Taylor's (1998) claim that there is no evidence for assortative mating in the two taxa. However, when non-specific mates are rare, many Cyanoramphus species seem to be able to hybridize successfully with any close congener, as observed on Mangere Island (Forbes' $\times$ Red-crowned 
Parakeets) and the Auckland Islands (Yellow $\times$ Red-crowned Parakeets). Taylor et al.'s (1986) captive breeding experiments showed the viability of Orangefronted $\times$ Yellow-crowned hybrids and an apparently simple genetic basis for plumage characters. In contrast, Grant and Grant (1992, 1997) reviewed the hybridization and speciation of birds and found that the late development of post-mating isolating factors during avian speciation results in $9.2 \%$ of presently described bird species being able to produce hybrid offspring in congeneric crosses. Moreover, the finding of a simple or complex genetic basis for any single characteristic of a bird does not fulfil the lead criteria of any species concept. This negates the idea that Taylor et al.'s (1986) captive cross breeding test is in any way applicable for species diagnosis in Cyanoramphus (or any other avian genus for that matter). There is always a possibility that gene flow may have occurred as a result of strictly directional hybridization between male Yellowcrowned and female Orange-fronted Parakeets. This would be undetected by mitochondrial DNA analysis and further work is presently under way (Chan et al. unpubl.) to test this hypothesis using nuclear microsatellite markers. For the present moment, this seems an unlikely prospect since there is no evidence of unidirectional hybridization in aviary crosses (Taylor et al. 1986). The fact that Yellow-crowned and Orange-fronted Parakeets are not sister taxa (Figures 6-8) makes it unlikely that they are conspecific. In consideration of the above molecular genetic and field data, we believe that the Orange-fronted Parakeet represents a genuinely distinct species, hence we reject the colour-morph hypothesis (Hypothesis 1) as proposed by Holyoak (1974), Taylor et al. (1986) and Taylor (1998) and classify it as Cyanoramphus malherbi after Triggs and Daugherty (1996) and Souance (1857).

Forbes' Parakeet The taxonomic rank of Forbes' Parakeet has been debated for the past 60 years (Fleming 1939, Nixon 1982, Triggs and Daugherty 1996). In spite of the marked differences that have been noted between Yellow-crowned and Forbes' Parakeets (morphology, vocalizations and allozyme electrophoresis data), the latter has been classified as a subspecies of Yellow-crowned Parakeet by most authorities (Forshaw 1989, Turbott 1990, Higgins 1999).

Our data resolve the relationship between Forbes' Parakeet and Yellowcrowned Parakeet with a high level of statistical support. The two criteria of diagnosability and monophyly required under the PSC are fulfilled, supporting the specific status of Forbes' Parakeet as C. forbesi. Based on our mitochondrial control region sequences, we classify Forbes' Parakeet as the most divergent New Zealand Cyanoramphus taxon (genetic distances of $6.85-7.87 \%$ to all other Cyanoramphus species). In our view, this warrants its elevation to full species status supporting Hypothesis 3 (see Introduction). For comparison, pairwise intergeneric comparisons for complete control region sequences from a wide variety of birds range from about 12 to 25\% (Baker and Marshall 1997). Often quite small genetic distances are found between firmly established bird species (Grant and Grant 1997, Avise 1983). This observation suggests that relatively few genetic changes may be involved in avian speciation and that the phenotypic effects of these changes are minor (Snell 1991). Consistent with Snell (1991), morphological differences between Forbes' Parakeet and other Cyanoramphus species are rela- 
tively small. Unlike the Orange-fronted Parakeet, the head colour of Forbes' Parakeet resembles that of the Yellow-crowned Parakeets, although it is more highly divergent. Thus, crown colour(s) may not be an entirely reliable taxonomic character.

Forbes' Parakeet is allopatric to its previously assigned conspecific Yellowcrowned Parakeet and therefore cannot be tested for reproductive isolation or compatibility of mate recognition systems according to the BSC and RSC; but using mitochondrial DNA data, we have fulfilled criteria for the PSC justifying specific status for Forbes' Parakeet. The Chatham Island subspecies of Redcrowned Parakeet $C$. $n$. chathamensis is the only sympatric congener of Forbes' Parakeet. One must therefore test the applicability of the BSC for Forbes' Parakeet based on its interactions with the Chatham Island Red-crowned Parakeet rather than the Yellow-crowned Parakeet. The BSC cannot be applied strictly in this case due to the high level of hybridization reported between Forbes' and Chatham Island Red-crowned Parakeet in the highly modified habitat on Mangere Island (Taylor 1975).

If the BSC were to be applied strictly and universally in avian systematics, many otherwise well-established species of parakeets and parrots would be judged to be conspecific. This is because post-zygotic isolating mechanisms appear to have evolved much later than pre-zygotic isolating mechanisms in the chronology of parrot speciation (Grant and Grant 1997). It is known that at least $7.5 \%$ (27 species) of Psittaciformes have bred with another species in the wild and produced fertile hybrids (Grant and Grant 1992). Thus, many parrot species, including Forbes' Parakeet and most other Cyanoramphus parakeets are actively speciating. Some have evolved effective pre-mating isolating mechanisms (e.g. Orange-fronted Parakeets), but may not have diverged far enough to satisfy the strict BSC definition. The RSC and CSC cannot be applied effectively in this case either. This is due to consideration of the extreme habitat modifications that have taken place on Mangere Island. Prior to deforestation of Mangere Island, Forbes' and the Chatham Island subspecies of Red-crowned Parakeets may not have been in contact, and may well have evolved effective ecological pre-mating isolating mechanisms based on differing habitat preferences. The absence of effective post-zygotic isolating mechanisms contributes to the present level of hybridization observed between these species. After deforestation, the modified vegetation (rank pasture) suited Chatham Island Red-crowned Parakeet better than Forbes' Parakeet and allowed rapid colonization of Mangere Island by the former. Forbes' Parakeet declined in numbers rapidly because of reduced opportunity for conspecific mate choice in the new habitat, ultimately leading to extensive hybridization with the Chatham Island Red-crowned Parakeet. The apparent lack of an effective pre-mating isolating mechanism in Forbes' Parakeet cannot therefore be used to test for species status. Nevertheless, we have presented evidence that a unique genotype is still present within Forbes' Parakeet, warranting recognition as a phylogenetic species. The conservation status of Forbes' Parakeet will not, however, be affected by its elevation to full species status because it is already being managed as a full species. Obtaining a larger sample size of DNA sequences would allow us to examine further the level of genetic cohesion that may exist within Forbes' Parakeet (Boon et al. unpubl.). 


\section{Phylogeny of Cyanoramphus}

The phylogenetic trees (Figures 6-8) produced using independent phylogenetic inference methods are broadly congruent. This indicates that our overall phylogenetic inference is robust and that there is a high probability that our trees reflect the true biological history of the mitochondrial DNA control region. Minor differences in the branching order between the trees have been found. It is sometimes prudent to investigate variation at more than one gene when assessing taxonomic status (Norman et al. 1998). Our analyses using cytochrome $b$ and control region provide different levels of phylogenetic resolution. They complement each other well and have no significant conflict between them. Although the loci are linked, conclusions supported by independent analysis of them increases the probability that we have inferred the correct phylogeny.

The phylograms (Figures 7 and 8) and cladogram (Figure 6) all show three well-supported major Cyanoramphus clades comprising Orange-fronted, Redcrowned and Yellow-crowned Parakeets. Ancestral to these are the Antipodes Island Parakeet and Forbes' Parakeet which form two relatively distant outgroups to the other species. Intraspecific variation within the main clades is highest for Red-crowned Parakeets, for which several well-described subspecies exist. The various Red-crowned Parakeet subspecies are sister species to the Orangefronted Parakeet. Our data support the current subspecific classification of the Chatham Island Red-crowned subspecies, C. n. chathamensis. The captive CD1212 Red-crowned Parakeet appears to be genetically distinct from the other Redcrowned Parakeet taxa, but no further conclusions can be made without detailed information on its origin. The low level of genetic heterogeneity and lack of population genetic structure observed within what is presently described as Yellow-crowned Parakeet suggests a high level of panmixia and does not provide support for Triggs and Daugherty's (1996) hypothesis on the separation of Northern/Southern genotypes. Larger sample sizes and more extensive geographic sampling of Yellow-crowned Parakeets from the North Island of New Zealand might provide the level of phylogenetic resolution needed to support or refute this hypothesis more firmly. The Orange-fronted Parakeet clade is formed by individuals whose control region sequences are all almost identical to one another, showing extreme genetic cohesion, further supporting their status as members of a distinct species. Contrary to some classifications (Triggs and Daugherty 1996), the molecular data for Forbes' Parakeet show a remarkably high level of divergence from those of all other Cyanoramphus species. These values are higher than those for any other intrageneric comparisons and it may possibly be one of the most ancient Cyanoramphus taxa. However, genetic data from more Forbes' Parakeet individuals will need to be examined in order to obtain a final phylogenetic resolution with respect to its origins and to search for molecular signals left by hybridization with other species (Boon et al. unpubl.).

\section{Conservation and summary}

The Orange-fronted Parakeet is highly endangered. Its geographical distribution is extremely limited, and it is presently only known for certain from two beech Nothofagus forest valleys in North Canterbury (Kearvell 1997). One of these popu- 
lations (Hope Valley) may now be extinct. The remaining known population in the Hurunui Valley may total less than 500 individuals (Kearvell 1997). Despite its uncertain taxonomic status and contrary to Taylor et al.'s (1986) conclusion, the Orange-fronted Parakeet is still maintained under Category " $\mathrm{A}$ " (highest priority for conservation action) by the New Zealand Department of Conservation (Tisdall 1994). This was done in order to ensure its conservation status would not be compromised before a taxonomic resolution was achieved. Our study confirms that this decision was prudent. Intensive management of its habitat by ongoing removal of stoats, deer, ferrets and possums is justified by the confirmation of its identity as a species under four different species concepts. Continued intensive management and ecological study of the small number of remaining birds is required for this species to recover from its endangered status.

Forbes' Parakeet is critically endangered. Numbers were once as low as 20-30 birds (Taylor 1975, 1985), and the current distribution is limited only to Mangere (112 ha) and Little Mangere (16 ha) Islands in the Chatham Group (Taylor 1975). The most recent population estimate indicates the number of Forbes' Parakeet to be approximately 100 (Mason et al. 1999). As numbers of Forbes' Parakeet declined, they hybridized with numerically superior Red-crowned Parakeets on Mangere Island, possibly due to breeding opportunities created by extensive modifications to vegetation from overgrazing, deforestation and introduction of predators (Taylor 1975). We have confirmed the species status of Forbes' Parakeet and, therefore, its population size should be closely monitored and active management of this species should be carried out to prevent its numbers declining further. Limiting numbers of Red-crowned and hybrid parakeets on Mangere Island, as is presently done, should continue to prevent genetic swamping of the Forbes' Parakeet gene pool. Our data show that, to date, such measures have effectively helped to preserve the genetic integrity of Forbes' Parakeet.

\section{Acknowledgements}

We thank Elizabeth McAvoy, Lesley Milicich, Rod Hitchmough and Thomas Buckley (IMS) for advice and technical support in the laboratory, Rod Hay as co-supervisor and reviewer for this paper, Andy Grant (DOC) for assistance in Yellow-crowned and Orangefronted Parakeet sample collections, Mike Bell (DOC) for Chatham Island Red-crowned Parakeet samples and Nga Manu Wildlife Sanctuary for specimen CD1212. We also thank Murray Williams, Lynette Clelland (DOC) and Rod Hitchmough (IMS) for reviewing the manuscript and providing valuable comments. This project was supported by New Zealand Department of Conservation and Victoria University of Wellington.

\section{References}

ABI Prism ${ }^{\mathrm{TM}}$ Big Dye ${ }^{\mathrm{TM}}$ Terminator Cycle Sequencing Ready Reaction Kit Protocol (1997) by Perkin-Elmer Corporation, California.

Anon (1997) Lasergene biocomputing software for Windows version 4. Madison, WI: DNASTAR.

Avise, J. C. (1983) Commentary on George F. Barrowclough's "Biochemical studies of microevolutionary processes". Pp. 223-270 in A. H. Brush, and G. A. Clark Jr, eds. Perspectives in ornithology. New York: Cambridge University Press. 
Avise, J. C. and Nelson, W. S. (1988) Molecular genetic relationships of the extinct Dusky Seaside Sparrow. Science 243: 646-648.

Baker, A. J. and Marshall, H. D. (1997) Mitochondrial control region sequences as tools for understanding evolution. Pp. 51-82 in D. P. Mindell, ed. Avian molecular evolution and systematics. San Diego: Academic Press.

Baum, D. and Shaw, K. L. (1995) Genealogical perspectives on the species problem. Monogr. Syst. Bot. 53: 289-303.

Birt, T. P., Friesen, V. L., Green, J. M., Montevecchi, W. A. and Davidson, W. S. (1992) Cytochrome $b$ sequence variation among parrots. Hereditas 117: 67-72.

Buller, W. L. R. (1869) On some new species of New Zealand birds. Trans. N.Z. Inst. 2: 390-392.

Cabot, E. (1998) XESEE 3.2 Eyeball sequence editor software.

Cottam, G. and Curtis, J. T. (1956) The use of distance measures in phytosociological sampling. Ecology 37: 451-460.

Cracraft, J. (1983) Species concepts and speciation analysis. Pp. 159-187 in R. F. Johnston, ed. Current Ornithology, 1. New York: Plenum Press.

Cracraft, J. (1997) Species concepts in systematics and conservation biology - an ornithological viewpoint. Pp. 325-339 in M. F. Claridge, H. A. Dawah and M. Wilson, eds. Species: the units of biodiversity. London: Chapman and Hall.

Dawson, R. J. G. (1992) A molecular examination of some enigmatic birds. PhD thesis, University of Nottingham, U. K.

Desjardins, P. and Morais, R. (1990) Sequence and gene organization of the chicken mitochondrial genome: a novel gene order in higher vertebrates. Mol. Biol. 212: 599-634.

Edwards, S. V., Arctander, P. and Wilson, A. C. (1991) Mitochondrial resolution of a deep branch in the genealogical tree for perching birds. Proc. R. Soc. Lond. B. 243: 99-107.

Elliott, G. P., Dilks, P. J. and O'Donnell, C. F. J. (1996) The ecology of Yellow-crowned Parakeets (Cyanoramphus auriceps) in Nothofagus forest in Fiordland, New Zealand. N. Z. J. Zool. 23: 249-265.

Falla, R. A., Sibson, R. B. and Turbott, E. G. (1966) A field guide to the birds of New Zealand, pp. 175-177. London: Collins.

Felsenstein, J. (1985) Confidence limits on phylogenies: an approach using the bootstrap. Evolution 39: 783-791.

Finsch, O. (1869) Remarks on some species of birds from New Zealand. Trans. N.Z. Inst. 2: 389-390.

Fleming, C. A. (1939) Birds of the Chatham Islands, 2. Emu 38: 492-509.

Forshaw, J. M. (1989) Parrots of the world, pp. 262-272. Melbourne, Australia: Landsdown.

Grant, P. R. and Grant, B. R. (1992) Hybridisation of bird species. Science 256: 193-197.

Grant, P. R. and Grant, B. R. (1997) Genetics and the origin of bird species. Proc. Natl. Acad. Sci. U.S.A. 94: 7768-7775.

Gray, G. R. (1862) List of Psittacidae in the British Museum. Ibis 4: 229.

Graybeal, A. (1995) Naming species. Syst. Biol. 44: 237-250.

Greene, T. J. (1998) Foraging ecology of the Red-crowned Parakeet (Cyanoramphus novaezelandiae novaezelandiae) and Yellow-crowned Parakeets (C. auriceps auriceps) on Little Barrier Island, Hauraki Gulf, New Zealand. N. Z. J. Zool. 22: 161-172.

Greig-Smith, P. (1964) Quantitative plant ecology. Second edition. Washington D.C.: Butterworth.

Gyllensten, U., Wharton, D., Josefsson, A. and Wilson, A. C. (1991) Paternal inheritance of mitochondrial DNA in mice. Nature 352: 255-257.

Harrison, M. (1970) The Orange-fronted Parakeet (Cyanoramphus malherbi). Notornis 17: $115-125$.

Helm-Bychowski, K. and Cracraft, J. (1993) Recovering phylogenetic signal from DNA sequences. Relationships within the Corvine assemblage (Class Aves) as inferred from 
complete sequences of the mitochondrial DNA cytochrome $b$ gene. Mol. Biol. Evol. 10: 1196-1214.

Higgins P. J., ed. (1999) Handbook of Australian, New Zealand and Antarctic birds, 4: Parrots to Dollarbird. Pp. 469-504. Melbourne, Australia: Oxford University Press.

Holyoak, D. T. (1974) Cyanoramphus malherbi, is it a colour morph of C. a. auriceps? Bull. Brit. Orn. Club 94: 4-9.

Irwin, D. M., Kocher, T. D. and Wilson, A. C. (1991) Evolution of the cytochrome $b$ gene of mammals. J. Mol. Evol. 32: 128-144.

Kearvell, J. (1997) Cyanoramphus malherbi and the colour morph question. Progress report for the 1995-1997 seasons. Unpubl. report, New Zealand Department of Conservation, Christchurch.

Kearvell, J. (1999) Orange-fronted (Cyanoramphus malherbi) and Yellow-crowned (C. auriceps) Parakeets: Breeding during the winter of 1999 in North Canterbury, a preliminary investigation. Unpubl. report, New Zealand Department of Conservation, Christchurch.

Kearvell, J. (2000) The use of transect counts and the Panel method for detecting trends in the population of the endangered Orange-fronted Parakeet (Cyanoramphus malherbi) in two North Canterbury valleys. Unpubl. report, New Zealand Department of Conservation, Christchurch.

Kocher, T. D., Thomas, W. K., Meyer, A., Edwards, S. V., Pääbo, S., Villablanca, F. X. and Wilson, A. C. (1989) Dynamics of mitochondrial DNA evolution in animals: Amplification and sequencing with conserved primers. Proc. Natl. Acad. Sci. U.S.A. 86: 61966200.

Kumar, S., Tamura, K. and Nei, M. (1993) MEGA: molecular evolutionary genetics analysis, version 1.01. University Park, PA: Pennsylvania State University.

Lansman, R. A., Avise, J. C. and Huettel, M. D. (1983) Critical experimental test of the possibility of "paternal leakage" of mitochondrial DNA. Proc. Natl. Acad. Sci. U.S.A. 80: 1969-1971.

Leeton, P. R. J., Christidis, L., Westerman, M. and Boles, W. E. (1994) Molecular phylogenetic affinities of the night parrot (Geopsittacus occidentalis) and the ground parrot (Pezoporus wallicus). Auk 111: 833-843.

Lopez, J. V., Yuhki, N., Masuda, R., Modi, W. and O'Brien, S. J. (1994) Numt, a recent transfer and tandem amplification of mitochondrial DNA to the nuclear genome of the domestic cat. J. Mol. Evol. 39: 174-190.

Mason, J., O'Connor, S., Baird, A., King, A. and King, S. (1999) Chatham Island update. Rare Bits 33: 13 (Unpublished quarterly update report, Biodiversity Recovery Unit, Department of Conservation, Wellington, New Zealand).

Mayr, E. (1942) Systematics and the origin of species. Pp. 119-122. New York: Columbia University Press.

Mayr, E. (1970) Populations, species and evolution. Pp. 10-20. Cambridge, MA: Harvard University Press.

Mindell, D. P., Sorenson, M. D. and Dimcheff, D. E. (1998) Multiple independent origins of mitochondrial gene order in birds. Proc. Natl. Acad. Sci. U.S.A. 95: 10693-10697.

Miyaki, C. Y., Matioli, S. R., Burke, T. and Wajntal, A. (1998) Parrot evolution and paleogeographical events - mitochondrial DNA evidence. Mol. Biol. Evol. 15: 544-551.

Moritz, C., Dowling, T. E. and Brown, W. M. (1987) Evolution of animal mitochondrial DNA: relevance for population biology and systematics. Annu. Rev. Ecol. Syst. 18: 269292.

Nixon, A. J. (1981) The external morphology and taxonomic status of the Orange-fronted Parakeet. Notornis 28: 292-300.

Nixon, A. J. (1982) Aspects of the ecology and morphology of Cyanoramphus parakeets 
and hybrids from Mangere Island, Chatham Islands. MSc thesis, Victoria University of Wellington, New Zealand.

Norman, J. A., Christidis, L., Westerman, M. and Richard Hill, F. A. (1998) Molecular data confirms the species status of the Christmas Island Hawk-owl Ninox natalis. Emu 98: 197-208.

Oliver, W. R. B. (1930) New Zealand birds, pp. 410-417. Wellington, New Zealand: Fine Arts New Zealand.

Oliver, W. R. B. (1955) New Zealand birds, pp. 554-564. Wellington, New Zealand: A. H. \& A. W. Reed.

Paterson, H. E. H. (1985) The recognition concept of species. Pp. 21-29 in E. S. Vrba, ed. Species and speciation. Pretoria: Transvaal Museum (Monogr. 4).

Pickard, J. (1990) Aspects of the behaviour and vocalisations of captive Antipodes Island parakeets (Cyanoramphus unicolor, Lear) and comparisons with other Cyanoramphus taxa. MSc thesis, Victoria University of Wellington, New Zealand.

Quinn, T. W. (1997) Molecular evolution of the mitochondrial genome. Pp. 3-28 in D. P. Mindell, ed. Avian molecular evolution and systematics. San Diego: Academic Press.

Rodríguez, J., Oliver, J. L., Marín, A. and Medina, J. R. (1990) The general stochastic model of nucleotide substitution. J. Theor. Biol. 142: 485-501.

Rothschild, W. (1893) Proc. Zool. Soc. London: 529.

Salvadori, T. (1891) Catalogue of the birds of the British Museum 20: 590.

Sambrook, J.; Fritsch, E.F.; Maniatis, T. 1989. Molecular cloning: a laboratory manual. Second edition. New York: Cold Spring Harbor Laboratory Press.

Simpson, G. G. (1961) Principles of animal taxonomy, pp. 152-155. New York: Columbia University Press.

Smith, M. F., Thomas, W. K. and Patton, J. L. (1992) Mitochondrial DNA-like sequences in the nuclear genome of an akodontine rodent. Mol. Biol. Evol. 9: 204-215.

Snell, R. R. (1991) Interspecific allozyme differentiation among North Atlantic whiteheaded larid gulls. Auk 108: 319-328.

Sorenson, M. D. and Fleischer, R. C. (1996) Multiple independent transpositions of mitochondrial DNA control region sequences to the nucleus. Proc. Natl. Acad. Sci. U.S.A. 93: 15239-15243.

Souance, Ch. De. (1857) Sescriptions de trois nouvelles espèces de Perroquets. Rev. Mag Zool. IX: 98.

Swofford, D. L. (1998) PAUP*. Phylogenetic analysis using parsimony (*and other methods), version 4. Sunderland, MA: Sinauer Associates.

Taylor, R. H. (1975) Some ideas on speciation in New Zealand parakeets. Notornis 22: 110121.

Taylor, R. H. (1985) Status, habits and conservation of Cyanoramphus parakeets in the New Zealand region. Pp. 195-211 in P. J. Moors, ed. Conservation of island birds. Cambridge, U. K.: International Council for Bird Conservation (Techn. Publ. 3).

Taylor, R. H. (1998) A reappraisal of the Orange-fronted Parakeet (Cyanoramphus sp.) species or colour morph? Notornis 45: 49-63.

Taylor, R. H., Heatherbell, E. G. and Heatherbell, E. M. (1986) The Orange-fronted Parakeet (Cyanoramphus malherbi) is a colour morph of the Yellow-crowned Parakeet (C. $a$. auriceps). Notornis 33: 17-22.

Templeton, A. R. (1989) The meaning of species and speciation: a genetic perspective. Pp. 3-27 in D. Otte and J. A. Endler, eds. Speciation and its consequences. Sunderland, MA: Sinauer Associates.

Tisdall, C. (1994) Setting priorities for the conservation of New Zealand's threatened plants and animals, p. 26. New Zealand Department of Conservation, Wellington.

Triggs, S. J. and Daugherty, C. H. (1996) Conservation and genetics of New Zealand parakeets. Bird Conserv. Internatn 6: 89-101. 
Turbott, E. G. (1990) Checklist of the birds of New Zealand and the Ross Dependency, Antarctica. Third edition. Wellington, New Zealand: Random Century and Ornithological Society of New Zealand.

Zhang, D. X. and Hewitt, G. M. (1996) Nuclear integrations: challenges for mitochondrial DNA markers. TREE 11: 247-251.

W. M. BOON, C. H. DAUGHERTY and G. K. CHAMBERS

Institute for Molecular Systematics, School of Biological Sciences, Victoria University of Wellington, P. O. Box 600, Wellington, New Zealand.

J. C. KEARVELL

New Zealand Department of Conservation, Canterbury Conservancy, Private Bag 4715, Christchurch, New Zealand. 
